\title{
Analysis and Extent of Santa Fe River Flooding in North Florida Attributed to Rainfall and Wind Damage Associated with Hurricane Irma
}

\author{
Sergio Bernardes, Lou Manglass, Sydney T. Bacchus, Marguerite Madden \\ Center for Geospatial Research (CGR), Department of Geography, University of Georgia, Athens, USA \\ Email:mmadden@uga.edu
}

How to cite this paper: Bernardes, S., Manglass, L., Bacchus, S. T., \& Madden, M. (2019). Analysis and Extent of Santa Fe River Flooding in North Florida Attributed to Rainfall and Wind Damage Associated with Hurricane Irma. Journal of Geoscience and Environment Protection, 7, 253-310. https://doi.org/10.4236/gep.2019.711019

Received: January 8, 2019

Accepted: November 26, 2019

Published: November 29, 2019

Copyright ( 2019 by author(s) and Scientific Research Publishing Inc. This work is licensed under the Creative Commons Attribution International License (CC BY 4.0).

http://creativecommons.org/licenses/by/4.0/ c) (i) Open Access

\begin{abstract}
The Santa Fe River (SFR) is within the north Florida area of the regional Floridan aquifer system. The extent of recent flood damage in the SFR and tributaries in Bradford County has been attributed to rainfall and wind damage to trees associated with Hurricane Irma, September 2017. Implications of the determined cause of a disaster can include the allocation of disaster relief funds. Bradford County, Florida obtained approximately $\$ 2.5$ million from the United States Department of Agriculture's (USDA) Natural Resources Conservation Service (NRCS) for emergency flood abatement assistance and $\$ 255,875$ from the Suwannee River Water Management District (SRWMD), combined with $\$ 13,750$ in-kind match provided by the county, based on the attributed cause of that damage to rainfall and winds from Hurricane Irma. On January 2, 2018, Bradford County commissioners also approved grant applications to the SRWMD for \$2.2 million for Alligator Creek Flood Mitigation and for $\$ 90,250$ for Hampton Lake Canal to Santa Fe River Flood Mitigation, requiring in-kind matches from the county of $\$ 110,000$ and $\$ 4750$, respectively. Our study analyzed historical precipitation data for the SFR Basin and headwaters from 1895 through 2017 and recorded discharge and gage heights from the United States Geological Survey (USGS) to evaluate that presumed cause of flood damage in that basin and to provide a better understanding of historical relationships between precipitation, gage data and flooding in that basin. Recorded USGS peak gage height and Digital Elevation Models (DEMs) also were used to illustrate the lateral extent and relative depth of flooding associated with an extreme precipitation event in the lower SFR vicinity of O'Leno State Park. Finally, we evaluated the condition of the trees in the SFR Basin as an indicator of long-term anthropogenic groundwater alterations. Those data and analyses did not support the conclusion that Hurricane Irma was the only cause of the magnitude and extent of SFR flooding
\end{abstract}


and tree damage in Bradford County and adjacent counties. Other contributors to stream flow in the SFR basin include heavy mineral mining wastewater discharges that have exceeded the maximum discharge volume of " 40 million gallons a day" (MGD) under the National Pollutant Discharge Elimination System (NPDES) permit issued by the Florida Department of Environmental Protection (FDEP) to the Chemours Company TT LLC (Chemours, formerly DuPont) for Trail Ridge mining operations. The magnitude of those discharges suggests that those discharges and extensive Trail Ridge mining in Baker, Bradford, Clay, and Duval Counties contributed to the flooding and were a factor in the tree destruction in the SFR Basin.

\section{Keywords}

Environmental Laws and Regulations, Extreme Weather, Federally Endangered Oval Pigtoe Mussel (Pleurobema pyriforme), Geographic Information System (GIS), Resource Sustainability

\section{Introduction}

\subsection{Background}

Hurricane Irma made landfall in the United States near Cudjoe Key in the lower Florida Keys as a category 4 storm on September 10, 2017. The hurricane weakened to a tropical storm by September 11, 2017, “when it was centered about 20 $\mathrm{n}$ mi west of Gainesville, Florida". The strongest winds of Hurricane Irma were confined to the northeast coast of Florida and southeastern Georgia and the center of Irma moved over southern Georgia west of Valdosta later that day. The system became a remnant when it crossed into Alabama on September 12, 2017 and continued northwestward while weakening and dissipated over southeastern Missouri shortly after, on September 13, 2017 (Cangialosi, Latto, \& Berg, 2018). Flooding of the Santa Fe River (SFR) and tributaries, and associated fallen trees in Bradford County, Florida during that time have been attributed to rainfall (precipitation) and wind damage from Hurricane Irma. Those presumptions were described in the United States Department of Agriculture's (USDA's) Natural Resources Conservation Service (NRCS) Damage Survey Report (DSR) number "IRMA-BRA-01" dated January 16, 2018. That 11-page USDA/NRCS DSR, under the "Emergency Watershed Protection" (EWP) Program, also included four pages of maps. One of those maps shows the upstream portion of this EWP "natural disaster" project for flood abatement and tree removal beginning at the north end of the on-going Chemours/DuPont Trail Ridge mining operations along the eastern boundary of Bradford County. Included with those maps is an illustration of stream cross-sections for "BEFORE CONSTRUCTION" and “AFTER CONSTRUCTION" and showing sediment removal that constitutes dredging in the stream channels as "debris removal". This flooding in Bradford County, attributed to Hurricane Irma rainfall and tree fall, appears to have been 
addressed initially in a "Special Called Meeting" by Bradford County commissioners on November 13, 2017, two months after Hurricane Irma, according to the minutes of that meeting. Based on those presumptions, Bradford County requested and received approximately $\$ 2.5$ million in emergency financial assistance from the USDA's NRCS for emergency flood abatement assistance. The county also requested and received $\$ 255,875$ from the Suwannee River Water Management District (SRWMD) and provided additional county funds as the required non-federal matching funds, for a total of $\$ 2,750,656.25$ in tax dollars from those three sources.

The NRCS division of the USDA was known as the Soil Conservation Service (SCS) until 1994. According to the USDA/NRCS, that agency provides financial and technical assistance to America's farmers, ranchers, and forest landowners to conserve the nation's soil, water, air, and other natural resources (USDA, 2018). Additionally, according to the agency, all programs are voluntary and offer science-based solutions that benefit both the landowner and the environment. Freedom of Information Act (FOIA) requests were submitted on June 22, 2018 and June 25, 2018 to the USDA/NRCS authors of the DSR report in Lake City, Florida and Gainesville, Florida. Those requests were for all documents providing background information, including information that may have been used to prepare the NRCS-PDM-20 form for the DSR emergency funding to Bradford County or to otherwise evaluate or authorize the grant. Public records requests also were submitted to Bradford County and to the SRWMD on June 22, 2018 and July 27, 2018. The documents received in response to the FOIA requests included no documents from any of those sources to support the presumption that recent record flooding of the SFR was caused by rainfall (precipitation) and wind damage to trees associated with Hurricane Irma in September 2017. The FOIA responses also included no documents to support the conclusion that the tree removal and dredging under the "Alligator Creek and Sampson River Flood Abatement and Tree Removal Project" would provide "Watershed Protection" for the SFR Basin or “conserve the nation's soil, water, air, and other natural resources".

Bradford County also submitted an 11-page "Final Reimbursement Request" to the Federal Emergency Management Agency (FEMA) dated June 18, 2018. That request was in the amount of $\$ 879,861.24$ for damage attributed to Hurricane Irma, including damage from flooding and debris removal. That "Final Reimbursement Request" also indicated that $10 \%$ of that total was reimbursable from the state and $10 \%$ was reimbursable from the county. The Bradford County "Hurricane Irma-FEMA DR\#4337 Final Reimbursement Request Summary and Historical Situation Report Summary" (Final Reimbursement Request) was released in June 2018 (unpublished request and report prepared by the Bradford County Sheriff's Office, 6/18). That request indicated that all area lakes, which are downstream of Alligator Creek, exceeded flood stage level. That request also included the following statements: 
Hurricane lrma made landfall in Bradford County the evening of September 10, 2017 as a Category 1 hurricane moving Northwest at $14 \mathrm{mph}$.

Alligator Creek reached record flood stage level.

The United States Geological Survey (USGS) gages are inactive on Alligator Creek, which is the subject of the "Alligator Creek and Sampson River Flood Abatement and Tree Removal Project." That same Alligator Creek also is where "40 million gallons a day" (MGD) of heavy mineral mining wastewater discharges by Chemours,' at discharge location D-001, are authorized under the National Pollution Discharge Elimination System (NPDES) permit issued by the Florida Department of Environmental Protection (FDEP).

\subsection{Approach}

This investigation employed established methods for the analysis of extreme precipitation and associated impacts, such as flooding and tree fall. In addition, we analyzed rainfall data and data derived from stream gages over time, and considered non-precipitation related factors that can increase the impact of extreme precipitation in the region of study. Those factors included industrial wastewater discharges, industrial groundwater withdrawals, hydroecology and relict geological features.

\subsubsection{Precipitation and Stream Data}

To evaluate the presumption that severe flooding and tree fall were caused by Hurricane Irma, we analyzed historical monthly precipitation data for the SFR Basin and the headwaters of the SFR in Bradford County from January 1895 through December 2017. We also evaluated monthly precipitation data during major storms that affected the SFR Basin and headwaters, including: Hurricane Dora (1964), "No Name Storm" (1993), Hurricanes Frances and Ivan (2004), Tropical Storms Beryl and Debby (2012), Hurricane Hermine (2016), and Hurricane Irma (2017). Those results and climatological normals were compared to recorded stream discharge and gage height data from the collaborative monitoring of USGS and SRWMD of the SFR and SFR tributaries to investigate and better understand relationships between precipitation and stream data associated with Hurricane Irma.

\subsubsection{Anthropogenic Alterations of Natural Hydroperiods}

Our initial review of precipitation data for the SFR Basin did not appear to support the conclusion that precipitation from Hurricane Irma alone was responsible for the magnitude of flooding in Bradford County and downstream in the lower SFR. A formal complaint filed with Bradford County on June 16, 2016 by Paul Still, Supervisor of the Bradford Soil and Water Conservation District, however, included photographic documentation and other information that mining operations, including discharges of heavy mineral mining wastewater by Chemours/DuPont that were occurring on land owned by the SRWMD in Bradford County, were not in compliance with Bradford County's Land Devel- 
opment Regulations (LDRs) and were resulting in flooding. That complaint, accessible as part of the public record, also stated that "captured stormwater is pumped to the DuPont site south of SR 230 and discharged into Alligator Creek and contributes to flooding in Starke and around Lakes Crosby and Sampson" (P. Still, unpublished public records). Imagery dated 1999 from the Bradford County Property Appraiser's website in that complaint showed mining along the southeastern portion of that SRWMD property in Bradford County, in addition to extensive mining to the east of the Bradford/Clay property line in Clay County. Subsequently, at the regular meeting of the Bradford County Board of County Commissioners on November 16, 2017, public comments were made by Paul Still that he had presented options to the SRWMD that the Bradford Soil and Water Conservation District had developed, to deal with the flooding. Those options included "temporarily ceasing Chemours discharge of water". Those comments were included on page 5 of the approved minutes of that Regular Meeting signed by Chairman Ross Chandler on January 18, 2018. Additional public comments were made by Paul Still, Supervisor of the Bradford Soil and Water Conservation District, at the regular meeting of the Bradford County Board of County Commissioners on December 4, 2017 regarding "Chemours continual discharge of water into Alligator Creek" (P. Still, unpublished public records) and were included in the minutes of that meeting signed and approved on February $7,2018$.

Based on that additional information, we also considered the locations and approximate magnitudes of long-term Trail Ridge mining and discharges of heavy mineral mining wastewater to the SFR Basin, initially by DuPont and currently by Chemours, as a potential contributing factor regarding the flooding and tree fall associated with Hurricane Irma in the SFR Basin. The causal role of anthropogenic alterations of natural hydroperiods from excessive groundwater withdrawals, as well as from mining, has been established within the regional karst Floridan aquifer system and has been described by Bacchus (1990, 1997a, 1997b, 1999, 2006, 2007); Bacchus, Archibald, Britton, \& Haines (2005); Bacchus, Hamazaki, Britton, \& Haines, (2000); Bacchus et al. (2003, 2011, 2014); and Bernardes et al. (2014). Adverse environmental impacts from those alterations of natural hydroperiods include premature decline and death of trees, as described in detail in those publications.

\subsubsection{Preferential Flow through Fractures}

An extensive network of fractures is characteristic of the regional Floridan aquifer system and has been mapped throughout Florida (FDOT, 1973; Vernon, 1951). Preferential flow through those fractures, in response to excessive groundwater withdrawals, aquifer injections, and mining, also has been described (Bacchus et al., 2011; Bacchus \& Barile, 2005; Bacchus, Bernardes, Xu, \& Madden, 2015; Bernardes et al., 2014; Lines et al., 2012; Xu, Bernardes, Bacchus, \& Madden, 2016). Adverse impacts from pirated water via preferential flow through fractures can include induced saltwater intrusion and induced recharge, 
altered natural hydroperiods, and dewatered wetlands and other surface waters (Bacchus, 2000; Bacchus et al., 2011; Krause \& Randolph, 1989; Lewelling, Tihansky, \& Kindinger, 1998; Metz \& Lewelling, 2009; Stewart \& Stedje, 1990; Watson, Stedje, Barcelo, \& Stewart, 1990).

Bernardes et al. (2014) conducted analyses of previously mapped fractures in Baker and Clay Counties, including fractures associated with Trail Ridge mining and groundwater withdrawals by DuPont in those counties associated with dewatering of relict sinkhole lakes and wetlands, in addition to premature decline and death of native trees. The dewatering of relict sinkhole lakes in the vicinity of DuPont's initial mining activities in that vicinity was referenced in a personal account that "two lakes in town mysteriously dried up" in 1948 or 1949, "shortly after DuPont began mining at a site across the border at Starke, Fla.", That account was included in an article by Gordon Jackson, published in the Florida Times Union on April 4, 1997 (Jackson, 1997). That initial Trail Ridge mining location is labeled and shown in Clay County, approximately $1.6 \mathrm{~km}(1 \mathrm{mi})$ east of the county line separating Bradford and Clay Counties on the "1949 Starke, Fla." USGS 7.5 minute topographic quadrangle map and approximately the same distance northwest of Stevens Lake. No other industrial activities, large-scale agricultural activities, or metropolitan areas were evident on that USGS topographic quadrangle map of rural Starke, Florida.

The premature decline and death of native trees described in Bernardes et al. (2014) predated the occurrence of Hurricanes Irma and Hermine by several years, and was consistent with the signs of long-term chronic water stress that had persisted in that area for years prior to that publication due to large-scale anthropogenic alterations of natural hydroperiods from excessive groundwater withdrawals and mining. Therefore, our approach to evaluating the presumption that severe flooding and tree destruction was caused by Hurricane Irma also included an evaluation of historical USGS photographs of trees associated with the SFR and tributaries to the SFR.

\subsection{Study Area}

Our study area was the SFR Basin, located in the north Florida area of the regional Floridan aquifer system (Figure 1). That regional aquifer system is one of the largest karst aquifer systems in the United States (US), underlying the entire state of Florida and the southeastern coastal plain portions of Alabama, Georgia, and South Carolina (Krause \& Randolph, 1989; Miller, 1986). The SFR Basin encompasses portions of the following ten counties: Alachua, Baker, Bradford, Clay, Columbia, Gilchrist, Lafayette, Putnam, Suwannee, and Union. The Santa Fe Swamp, located in Bradford County, is the headwaters of the SFR. Based on the unpublished documents from Bradford County described previously that attributed the flooding in that county to Chemours' heavy mineral mining wastewater discharges in Bradford County, evaluation of on-going Chemours/DuPont Trail Ridge mining operations initially was confined to Bradford County for our 


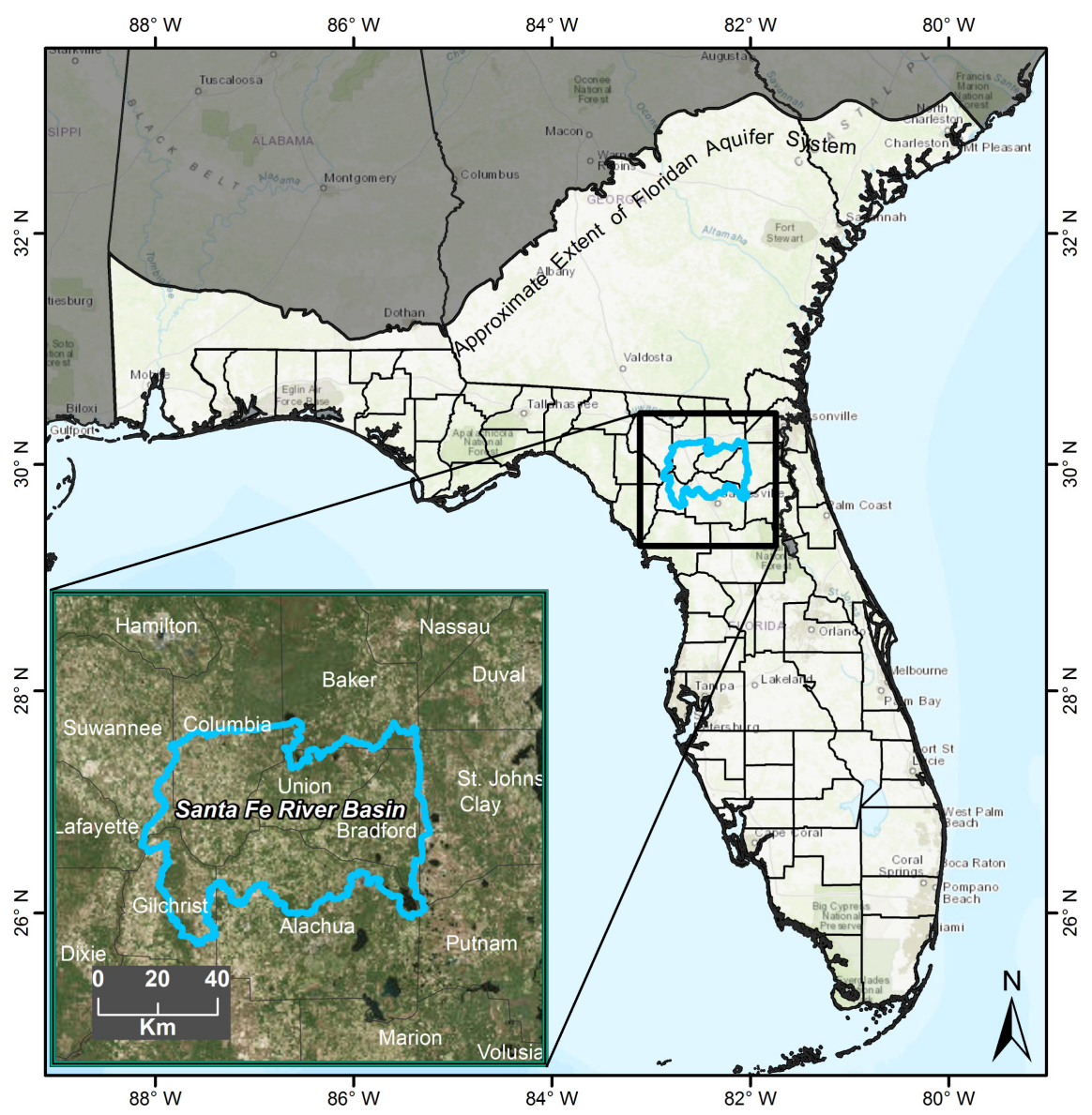

Figure 1. Santa Fe River Basin area of study, located in the north Florida portion of the regional Floridan aquifer system and including parts of Alachua, Baker, Bradford, Clay, Columbia, Gilchrist, Lafayette, Suwannee, and Union Counties, over World Topo Map and World Imagery basemaps.

study. More detailed examination revealed that the Chemours/DuPont Trail Ridge mining operations extended into contiguous Baker, Clay, and Duval Counties, which also could be contributing to the flooding in downstream areas of the SFR and were included in our study area. Some of the Chemours/DuPont Trail Ridge mining operations extend beyond the boundaries of the SFR Basin in Baker and Clay Counties.

\section{Materials and Methods}

\subsection{Precipitation Data and Analyses}

This investigation used 123 years of precipitation data (January 1895 to December 2017) provided by the Parameter-elevation Regressions on Independent Slopes Model (PRISM) Climate Group (PRISM, 2018a). Total monthly precipitation was analyzed using two spatial domains: 1) the SFR Basin (WBDHU8 level) defined by the USGS Watershed Boundary Dataset (WBD) for 2-digit Hydrologic Unit-03 (published May 1, 2018); and 2) the location of the USGS SFR Near Graham station (02320700). The SFR Near Graham gage station is located 
at latitude $29^{\circ} 50^{\prime} 45^{\prime \prime} \mathrm{N}$, longitude $82^{\circ} 13^{\prime} 10^{\prime \prime} \mathrm{W}$. That gage station is the closest active USGS gage station to the SFR headwaters, approximately $8 \mathrm{~km}(5 \mathrm{mi})$ west of the Santa Fe Swamp.

Total monthly precipitation was averaged for the SFR Basin using Google Earth Engine (https://earthengine.google.com/) and WBD files downloaded from the National Map Download Viewer (https://viewer.nationalmap.gov/basic/). Monthly precipitation data for the SFR near Graham gage station were retrieved using the data explorer tool from PRISM (2018b). Time series analyses and the identification of climatological normals for the SFR area of study and the SFR Near Graham gage included the computation of 30-year averages of monthly precipitation for three periods (1928-1957, 1958-1987, and 1988-2017).

\subsection{Shapefiles and Other Data Obtained from Agencies}

The shapefiles for the SFR Basin used in this study were obtained from the USGS WBD. The sub-regions of the Floridan aquifer system included in Figure 1 were created using widely-accepted map vectorization procedures, including the control-point based georeferencing of the sub-regions map included in Krause \& Randolph (1989) and the heads up digitizing of the resulting georeferenced map image (Xu et al., 2016). Shapefiles for USGS active and inactive gage locations for surfacewater monitoring were obtained from the USGS National Water Information System (NWIS) (USGS NWIS, 2018) for south and north Alligator Creeks in Bradford County; the New River in north central Florida; Olustee Creek; the Sampson River; and the SFR. Graphs of stream discharges and gage heights also were obtained from NWIS. Labels for peak stream discharges and gage heights occurring during the months and years when Hurricane Dora, the "No Name Storm," Hurricanes Frances and Ivan, Tropical Storms Beryl and Debby, Hurricane Hermine, and Hurricane Irma affected the SFR Basin were added to those NWIS graphs to facilitate comparisons of those storm events.

The periods of record for the active USGS monitoring stations considered in our study are not consistent within or among those locations. The periods of record for the SFR near Graham began October 1, 1986 for stream discharges and October 1, 2009 for gage heights. The periods of record for the SFR at Worthington Springs (02321500) began October 1, 1986 for stream discharges and October 1, 2007 for gage heights. The periods of record for the SFR at O'Leno State Park (02321898) began January 10, 2011 for stream discharges and June 9, 2010 for gage heights. Those dates, for initiation of monitoring at the SFR at O'Leno State Park location, are approximately 47 years after Hurricane Dora and six years after Hurricanes Frances and Ivan. The periods of record for the SFR at River Rise (02321958) did not begin until October 1, 2015 for both stream discharges and gage heights and cannot be used for comparisons of dates for any of the hurricanes or tropical storms evaluations in our study except for Hurricanes Hermine (2016) and Irma (2017). The periods of record for the New River near Lake Butler (02321000), the only SFR tributary with an active monitoring site, began October 6, 1990 for stream discharges and October 1, 1990 for gage 
heights.

The latitudes and longitudes for the Chemours Company TT LLC (Chemours, formerly DuPont) Florida Trail Ridge Mine discharge locations and volumes for heavy mineral mining wastewater permitted in Baker County were obtained from the FDEP's major permit for industrial wastewater FL0435490 (file number FL0435490-007-IW3S), effective for May 15, 2016 through May 14, 2021. The most recent modification of that permit (009) was issued by FDEP on October 31, 2018. Considerable daily discharges of Chemours' heavy mineral mining wastewater will continue under that modification, without consideration of potential flooding downstream of those discharge locations. The latitudes and longitudes for discharge locations D-001 and D-002, and volumes for discharges of Trail Ridge heavy mineral mining wastewater permitted in Bradford County by the FDEP were obtained from the FDEP's revised major NPDES permit FL0000051 (file number FL0000051-012-IW3S), effective June 29, 2017 through June 28, 2022. The location of Outfall D-001 was reported to be "located approximately at latitude $29^{\circ} 55^{\prime} 25^{\prime \prime} \mathrm{N}$, longitude $82^{\circ} 03^{\prime} 43^{\prime \prime} \mathrm{W}$ ". The location of Outfall D-002 was reported to be "located approximately at latitude $29^{\circ} 54^{\prime} 38^{\prime \prime} \mathrm{N}$, longitude $82^{\circ} 02^{\prime} 12^{\prime \prime}$ ". Shapefiles of those heavy mineral mining wastewater discharge locations in Baker and Bradford Counties were created from those latitude and longitude coordinates. The boundaries of the proposed and existing Chemours/DuPont Trail Ridge mining operations and groundwater supply wells authorized by St. Johns River Water Management District (SJRWMD) consumptive use permits (CUPs) for the initial mining in Clay County were provided by the SJRWMD and were the same shapefiles used in the analysis by Bernardes et al. (2014). These are not the only CUP wells that may occur or have occurred during that mining operation. The acquisition and methods for the FDOT (1973) and Vernon (1951) mapped lineaments indicative of fractures in Florida were described in Bacchus et al. (2014), Bernardes et al. (2014), and Lines et al. (2012). The Digital Elevation Models (DEMs) used to illustrate the lateral extent and relative depths of flooding associated with Hurricane Irma in the lower SFR vicinity of O'Leno State Park and Buzzards Roost Prairie, were obtained from the SRWMD.

\subsection{Spatial Extent and Relative Depths of Peak Flooding in the Lower Santa Fe River Associated with Hurricane Irma}

A preliminary analysis of the spatial extent of the September 2017 flood event in the area of study was conducted using the DEMs from the SRWMD, a reference surface simulating water level, and the software ArcScene, version 10.6 (ESRI). The DEM (terrain elevation) used by our study derived from high-accuracy Light Detection And Ranging (LiDAR) technology (RMSEz of checkpoints for non-vegetated areas not higher than 0.055 meters or 0.18 feet) and results from processing of LiDAR point clouds acquired by flights in 2011 (Northrop Grumman, 2011), 2013 (Digital Aerial Solutions, 2013) and in January and February 2017 (Dewberry, 2017). The elevation data from the SRWMD were received as 
three elevation surfaces (Alachua, Ichetucknee, and Upper Santa Fe). These surfaces have a horizontal posting space of 0.8 meters ( 2.5 feet) and are referenced to the NAD83 horizontal datum and the NAVD88 vertical datum. Prior to processing, the three elevation surfaces were combined into a single elevation-layer mosaic.

The preliminary analysis using ArcScene consisted of simulating flood by moving the water level layer vertically to user-defined elevations according to gage readings and what-if-scenarios. The elevation model was set as a static layer and was used as background to visually verify the locations where the water level was above the elevation model. This analysis, although informative, did not account for continuity and potential barriers to water movement resulting from changes in local topography. Continuity analysis of the lower SFR peak-flood area was incorporated into our study by using a modified version of the National Oceanic and Atmospheric Administration's (NOAA) method for mapping sea level rise inundation (NOAA, 2017). The method is used by the NOAA Office for Coastal Management and consists of a modified bathtub approach that accounts for hydrological connectivity. Processing of DEMs used ArcGIS 10.6 with Spatial Analyst extension enabled (ESRI).

That peak flood level during Hurricane Irma was investigated using USGS gage SFR at O'Leno State Park, Florida, latitude $29^{\circ} 55^{\prime} 35.63^{\prime \prime} \mathrm{N}$, longitude $82^{\circ} 33^{\prime} 34.73^{\prime \prime} \mathrm{W}$, horizontal datum NAD83, vertical datum NAVD88. This gage, located in Columbia County, Florida, is part of USGS Hydrologic Unit 03110206, and has a contributing drainage area of 212,379 hectares (820 square miles, https://waterdata.usgs.gov/nwis/measurements/?site_no $=02321898)$. This is the closest SFR gage upstream of Buzzard's Roost Prairie, in Columbia County, and the lower SFR (west of Interstate 75 and east of Highway 41), in Alachua County. This area of the lower SFR experienced extensive, severe, and prolonged flooding in September 2017, during and following Hurricane Irma. Gage height at this location has been collected since June 2010, including daily gage height data before, during, and after Hurricane Irma. Those data are provided at the USGS data portal

(https://waterdata.usgs.gov/nwis/dv?referred_module=sw\&site_no=02321898).

Horizontal and vertical datum matched the reference DEM dataset and no datum transformation was required to analyze the datasets. Our modified bathtub approach used the peak gage height associated with Hurricane Irma to depict the extent and relative depth of that flooded area. The following methodology was applied to generate and analyze the extent and the depth of the continuous body of water during peak flooding:

1) Create a "water level at gage" image (WLevel) that matches the extent and pixel locations of the DEM. Elevation values for all pixels in this WLevelimage are equal to the gage reading being analyzed. ArcGIS tool used: Raster Calculator.

2) Create a water depth image (WDepth) following: if DEM is less or equal WLevel, then WDepth receives WLevel minus DEM. ArcGIS tool used: Raster Calculator. 
3) Create a water mask image (WMask), following: if DEM is less or equal WLevel, then WMask receives the value 1. ArcGIS tool used: Raster Calculator.

4) Evaluate connectivity of WMask and create WMConnectivity image. ArcGIS tool used: Region Group, under Spatial Analyst (number of neighbors used: eight).

5) Inspect WMConnectivity for connectivity value (CValue) at the location of gage station. ArcGIS tool used: Identify tool.

6) Create image of connected water mask pixels (WMCExtracted) by extracting pixels from WMConnectivity that have numbers for the Value field equal to CValue. ArcGIS tool used: Extract by Attributes, under Spatial Analyst.

7) Create image of connected depth image pixels (WDConnected) by extracting pixels from WDepth using WMCExtracted as reference. ArcGIS tool used: Extract by Mask, under Spatial Analyst.

\section{Results}

\subsection{Historical Precipitation}

Figure 2 illustrates the total monthly precipitation for the SFR Basin (WBDHU8) from January 1895 to December 2017. Total monthly precipitation for that period of record for the SFR headwaters in Bradford County is not shown because it was comparable to results for the SFR Basin in Figure 2. The vertical columns of alternating shading (background) in this figure separate each decade of monthly precipitation data. Alternating colors were used for even and odd months, to facilitate viewing of the data. The horizontal dashed line across the period of record is positioned at the peak total monthly precipitation for Hurricane Irma, during September 2017 (309.4 mm or $12.2 \mathrm{in}$ ). This horizontal line allows comparisons of total monthly precipitation for Hurricane Irma to total precipitation for preceding months dating back to January 1895. Figure 2 shows that total monthly precipitation for Hurricane Frances and Ivan in September 2004 (474.8 mm or $18.7 \mathrm{in}$ ) and for Tropical Storm Debby in June 2012 (520.1

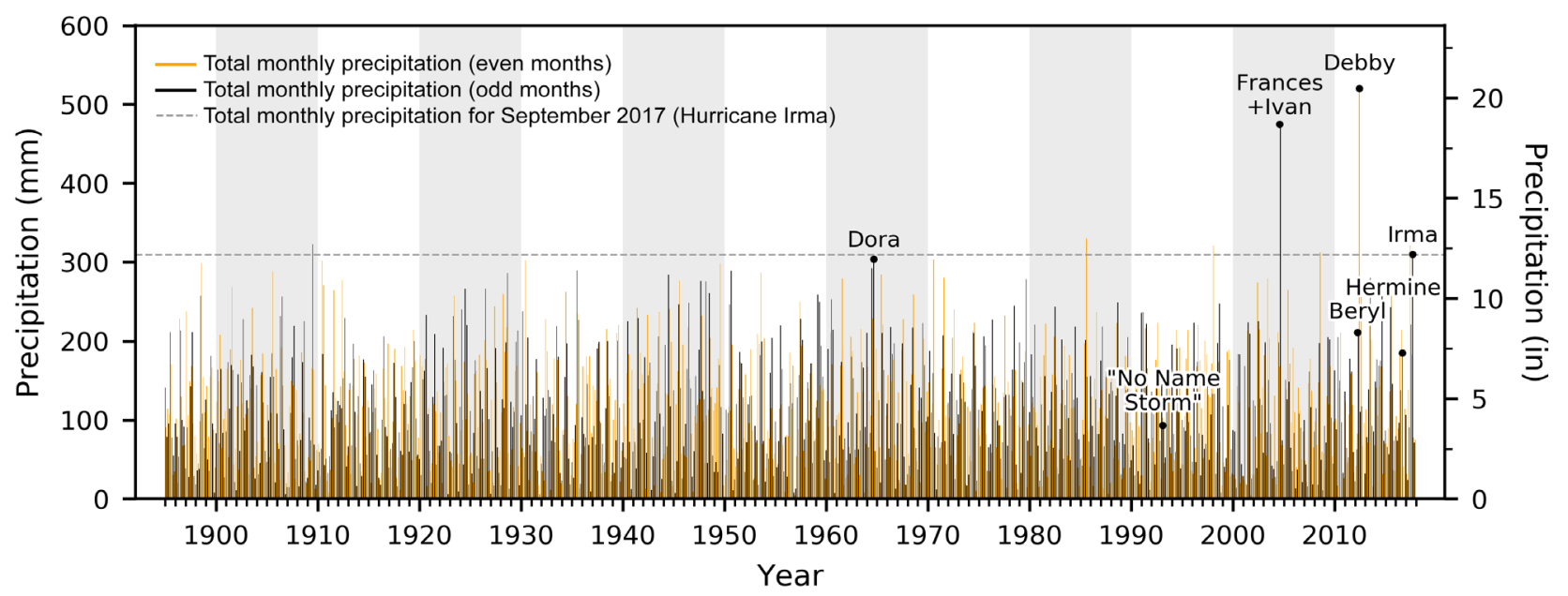

Figure 2. Total monthly precipitation for the Santa Fe River Basin (WBDHU8) from January 1895 to December 2017, with months labelled for occurrences of Hurricane Dora (1964), the "No Name Storm" (1993), Hurricanes Frances and Ivan (2004), Tropical Storms Beryl and Debby (2012), Hurricane Hermine (2016), and Hurricane Irma (2017). 
mm or 20.5 in) both exceeded total monthly precipitation for the month of Hurricane Irma (September 2017). Figure 2 also shows four additional peaks of total monthly precipitation that exceeded total monthly precipitation for the month of Hurricane Irma, but were not described or named as flooding events by or in Bradford County. Those peaks (not labelled in Figure 2) occurred in August 1985 (329.6 mm or 13 in), February 1998 (320.6 mm or 12.6 in), August 2008 (312.1 $\mathrm{mm}$ or $12.3 \mathrm{in}$ ), and June 2017 (321.1 mm or $12.6 \mathrm{in}$ ). Following is the chronological order of storms and hurricanes, including month, year and total monthly precipitation, that have been identified by Bradford County, funding agencies, and other agencies and individuals as causing flood events in the SFR Basin and that were considered in our study: Hurricane Dora (9/64 - $304.3 \mathrm{~mm}$ or 12 in); "No Name Storm" (3/93 - 93.2 mm or 3.7 in); Hurricanes Frances + Ivan (9/04 - $474.8 \mathrm{~mm}$ or $18.7 \mathrm{in})$; Tropical Storm Beryl (5/12 - 211.3 mm or 8.3 in); Tropical Storm Debby (6/12 - $520.1 \mathrm{~mm}$ or $20.5 \mathrm{in})$; Hurricane Hermine (9/16 - $185.8 \mathrm{~mm}$ or $7.3 \mathrm{in})$; Hurricane Irma (9/17 - 309.4 $\mathrm{mm}$ or $12.2 \mathrm{in})$.

Figure 3(a) provides a more detailed comparison of the total monthly precipitation for the storms and hurricanes influencing the SFR Basin that are labelled in
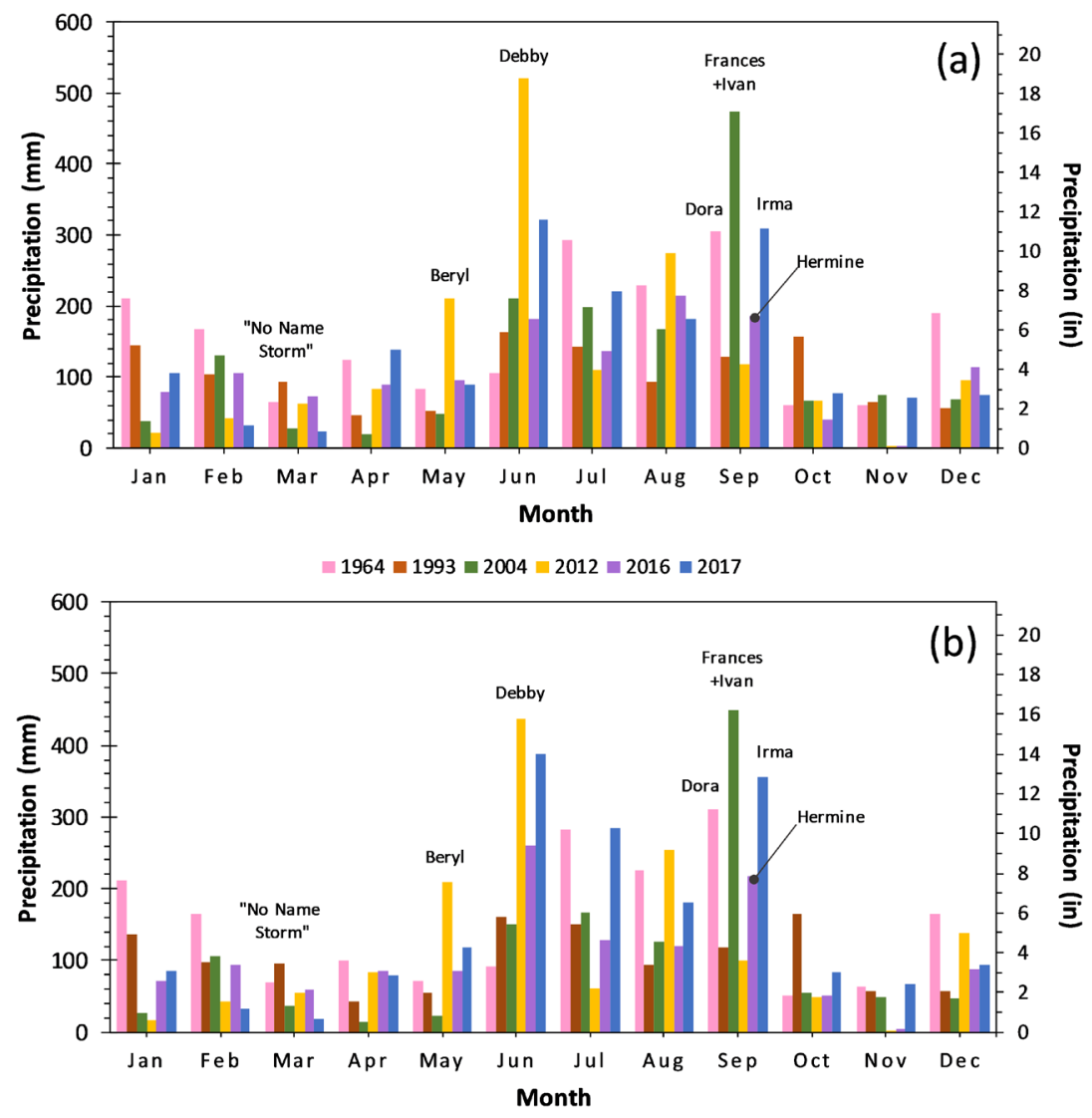

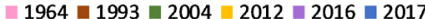

Figure 3. Total monthly precipitation for 1964, 1993, 2004, 2012, 2016, and 2017, with months identified for the storms and hurricanes labelled in Figure 2, for: (a) entire Santa Fe River Basin and (b) Santa Fe River headwaters at the USGS Santa Fe River Near Graham gage station. 
Figure 2. Figure 3(b) also displays the total monthly precipitation for those storms and hurricanes labelled in Figure 2 based on total monthly precipitation for the SFR headwaters in Bradford County at the USGS SFR Near Graham gage station. This SFR gage station is the nearest active gage station to the Santa $\mathrm{Fe}$ Swamp, which is the headwaters of the SFR and located upstream of that gage station.

Based on the total monthly precipitation for the SFR Basin, the total precipitation values for the months of the tropical storms and hurricanes considered in our study (Figure 2 and Figure 3) were, from least to greatest: "No Name Storm" (93.2 mm or 3.7 in) < Hermine $(185.8 \mathrm{~mm}$ or $7.3 \mathrm{in})<$ Beryl $(211.3 \mathrm{~mm}$ or $8.3 \mathrm{in})<$ Dora $(304.3 \mathrm{~mm}$ or $12 \mathrm{in})<\operatorname{Irma}(309.4 \mathrm{~mm}$ or $12.2 \mathrm{in})<$ Frances + Ivan $(474.8 \mathrm{~mm}$ or $18.7 \mathrm{in})<$ Debby $(520.1 \mathrm{~mm}$ or $20.5 \mathrm{in})$. Results of the analysis of average total monthly precipitation for the three 30-year periods of 1928-1957, 1958-1987, and 1988-2017 are provided in Figure 4(a) for the entire SFR Basin and in Figure 4(b) for the SFR headwaters at the USGS SFR Near Graham gage station, west of the Santa Fe Swamp headwaters.
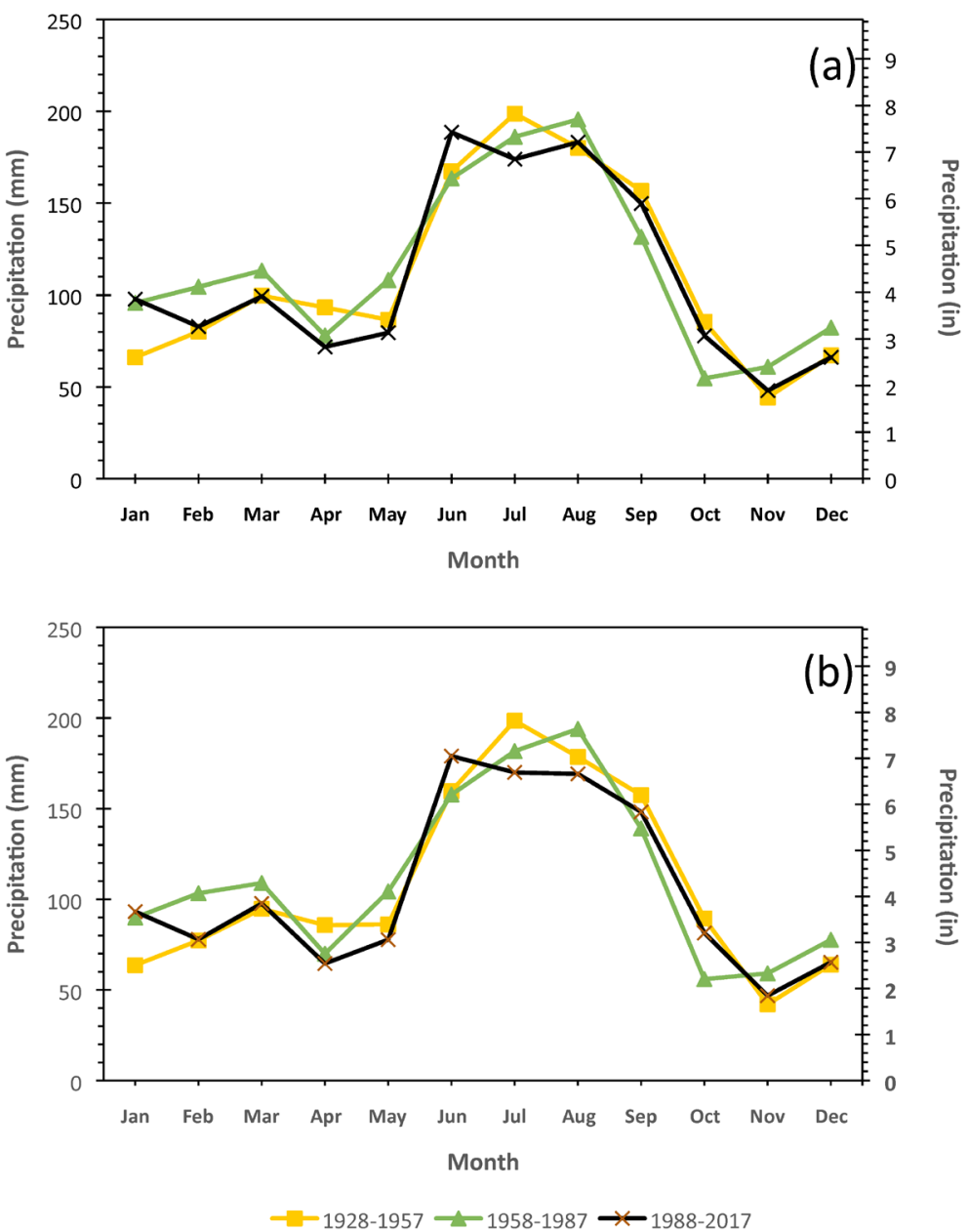

Figure 4. Average total monthly precipitation for three 30-year periods (1928-1957, 1958-1987, and 1988-2017) for: (a) entire Santa Fe River Basin and (b) Santa Fe River Near Graham gage station. 


\subsection{Historical USGS Stream Discharges, Gage Heights, and Photographs}

\subsubsection{Historical USGS Stream Discharges and Gage Heights}

The locations of all of the USGS gage stations for the SFR and tributaries Alligator Creek, New River, Olustee Creek, and Sampson River are shown in Figure 5. The UGSG gage locations illustrated by the diamond symbol are the only active USGS gages. Only one of those gages in the New River and only four of the gages in the SFR are active within the area of interest in our study, west from the SFR headwaters to the Highway 41 Bridge, which is north of High Springs, Florida. The remaining USGS gage locations that are inactive are illustrated by circle symbols that are color-coded by the stream where those inactive gages are located. The

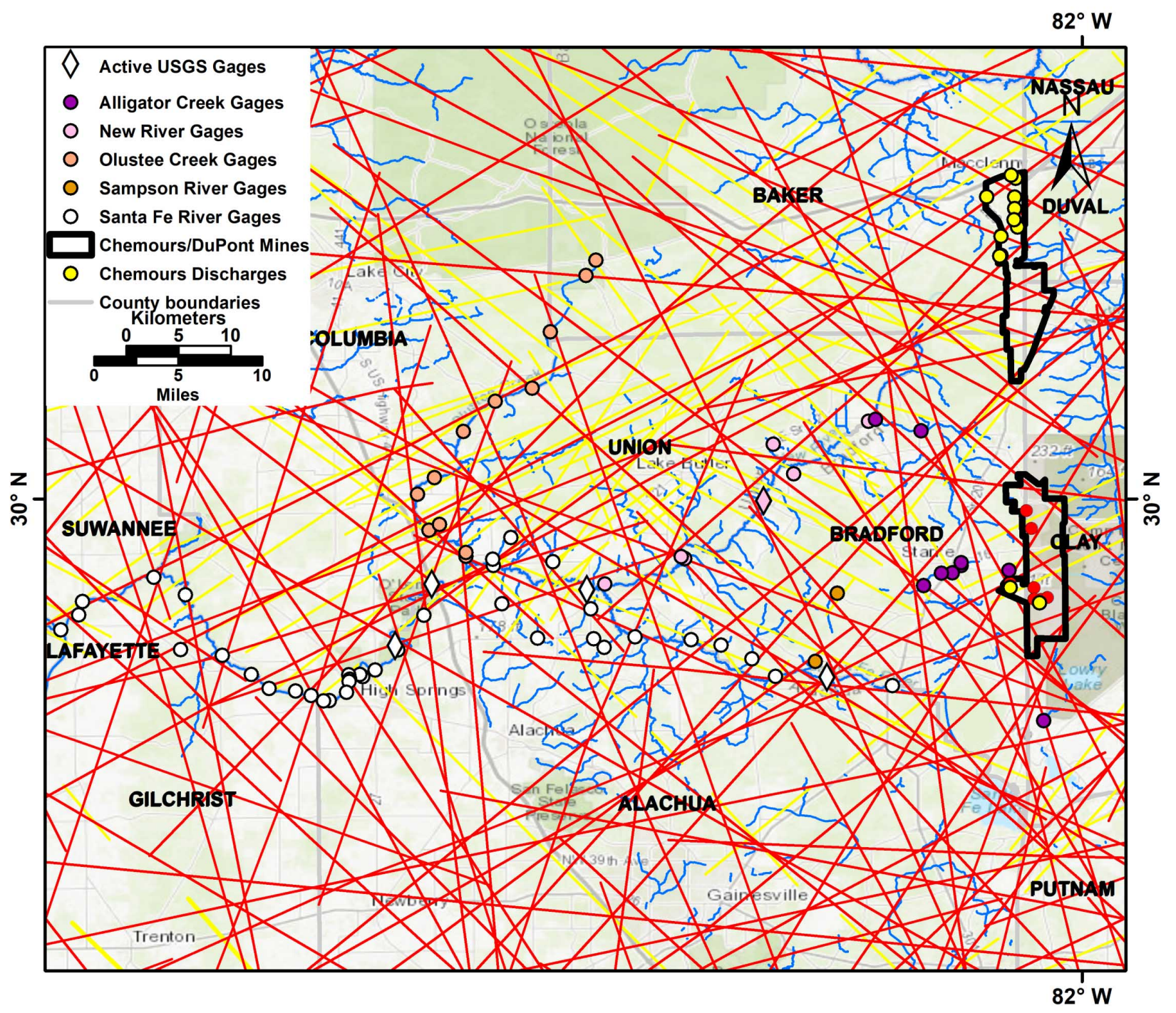

Figure 5. Location of the USGS monitoring stations for the Santa Fe River and tributaries Alligator Creek, New River, Olustee Creek, and Sampson River (in blue), including the five active gages west from the SFR headwaters to the Highway 41 bridge north of High Springs, Florida, over World Topo Map basemap, with mapped fractures by FDOT (1973) as diagonal red lines, mapped fractures by Vernon (1951) as diagonal yellow lines, and the CUP wells pumping ground water from the Floridan aquifer system as red circles. 
yellow circles in Figure 5 indicate the locations for Chemours' permitted wastewater discharges. The red circles in Figure 5 indicate the locations for the CUP wells identified in the analysis by Bernardes et al. (2014) for groundwater withdrawals from the Floridan aquifer system for Trail Ridge mining operations. The reason for the inactivity of the remaining gages was attributed to limited funding for the USGS, rather than irrelevance of those data (USGS, personal communication, R. Knapp 12/18), suggesting data from those gages could have provided valuable information regarding the source of flooding in the SFR Basin and should be re-activated. The single active USGS gage monitoring station in the New River is New River Near Lake Butler (02321000). As of September 2017, the four active USGS gage stations in the SFR, within the study area, were (from east to west): SFR Near Graham (02320700), SFR at Worthington Springs (02321500), SFR at O'Leno State Park (02321898), and SFR at River Rise Near High Springs (02321958). Those active USGS gage monitoring stations in the New River and SFR are identified by diamond symbols in Figure 5 .

Figure 5 also shows the boundaries for Chemours Trail Ridge mining operations, east of the Osceola National Forest in Baker, Bradford, Clay, and Duval Counties to the north and in Bradford and Clay Counties to the south. Also shown in Figure 5 are the discharge locations for the Chemours heavy mineral mining wastewater permitted by FDEP and the locations of the SJRWMD CUP groundwater supply wells (red circles) used for the Chemours Trail Ridge mining operations in the southern boundary area in Baker and Clay Counties, as identified in Bernardes et al. (2014). This figure also includes the fractures mapped by FDOT (1973, red diagonal lines) and by Vernon (1951, yellow diagonal lines). Vernon (1951) focused on mapping the fracture network of an area of north Florida, while the Remote Sensing facility of FDOT (1973) mapped a more extensive fracture network and covered the entire state. Both mapped fracture networks are relevant to our study area.

Figure 6(a) and Figure 6(b) provide the USGS graphs for historical stream

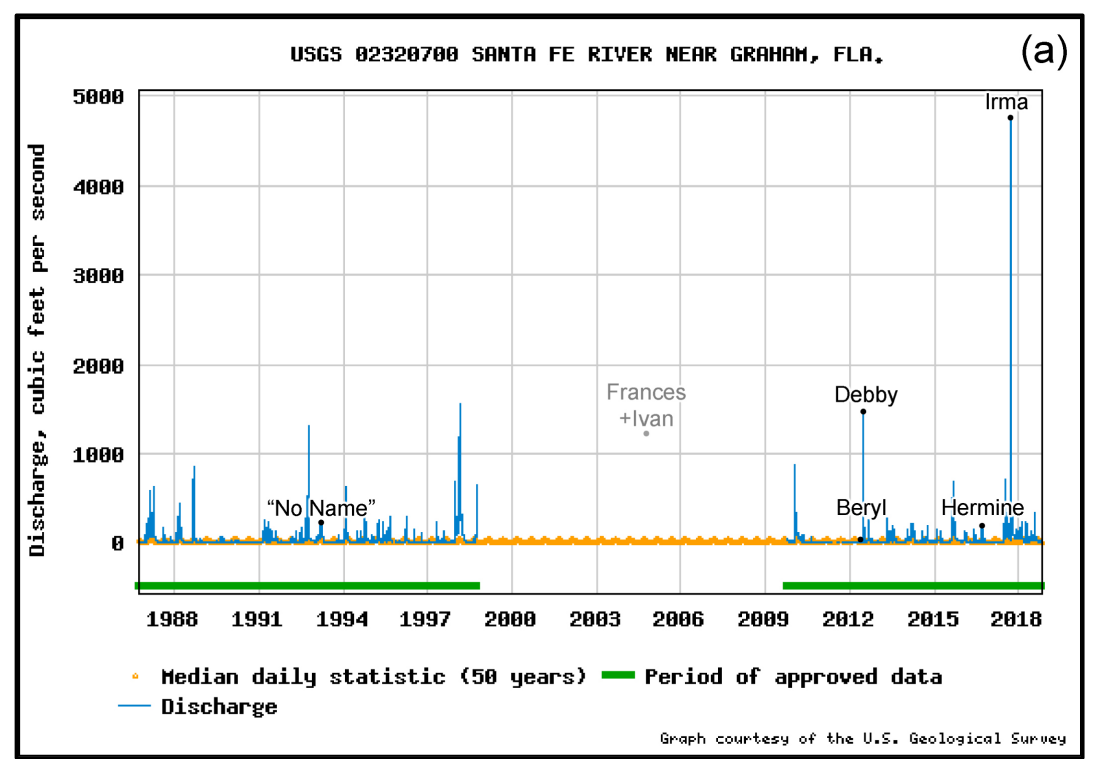




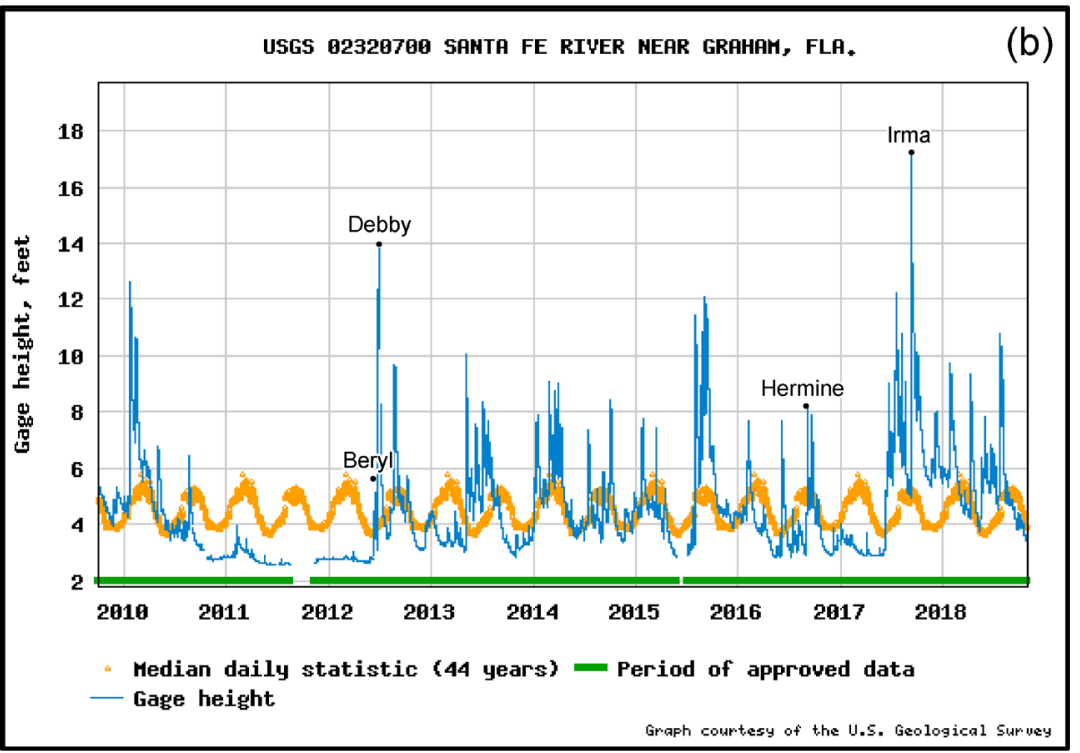

Figure 6. USGS graphs for the Santa Fe River Near Graham gage station of historical: (a) discharges from October 1, 1986 through 2018 and (b) gage heights from October 1, 2009 through 2018.

discharges from 1986-2018 and historical gage heights from 2009-2018, respectively, for the USGS SFR Near Graham, west of the headwaters in the Santa Fe Swamp (retrieved on February 2, 2019). There is a gap of missing USGS stream discharge data at this gage station from approximately 1998-2009. That period of missing data includes the 2004 period when the SFR experienced Hurricanes Frances and Ivan. The stream discharge data for that month was obtained from the USGS cooperating agency data set maintained by the SRWMD. For periods during which the USGS is not collecting or maintaining data from gage stations those data may be available from the local source, which in this case is collected by P. Still, Supervisor of the Bradford Soil and Water Conservation District (personal communication, P. Still, 2/19). Those data not included in the USGS graph in Figure 6(a), but retrieved from the local source, show approximately 1000 cubic feet per second $\left(\mathrm{ft}^{3} \mathrm{Sec}^{-1}\right)$ more flow from this SFR location during Frances and Ivan in September 2004, than during the "No Name Storm" in March of 1993, which is equivalent to approximately $28.3 \mathrm{~m}^{3} \mathrm{sec}^{-1}$. There were no stream discharge records for Tropical Storms Beryl and Debby in May and June of 2012, respectively, but approximately $141.6 \mathrm{~m}^{3} \mathrm{sec}^{-1}\left(5000 \mathrm{ft}^{3} \mathrm{sec}^{-1}\right)$ stream discharge was recorded during Hurricane Irma in September 2017. That record discharge occurred with precipitation significantly less than during Hurricanes Frances + Ivan and Tropical Storm Debby. Gage height from this SFR location also recorded a record of approximately $5.2 \mathrm{~m}$ (17 ft) or Hurricane Irma, compared to approximately $4.3 \mathrm{~m}$ (14 ft) for Tropical Storm Debby.

Figure 7(a) and Figure 7(b) provide the USGS graphs for historical stream discharges from 1986-2018 and historical gage heights from 2007-2018, respectively, for the SFR at Worthington Springs. These graphs show similar responses of record stream discharge and gage height of $671.1 \mathrm{~m}^{3} \mathrm{sec}^{-1}\left(23,700 \mathrm{ft}^{3} \mathrm{sec}^{-1}\right)$ and 

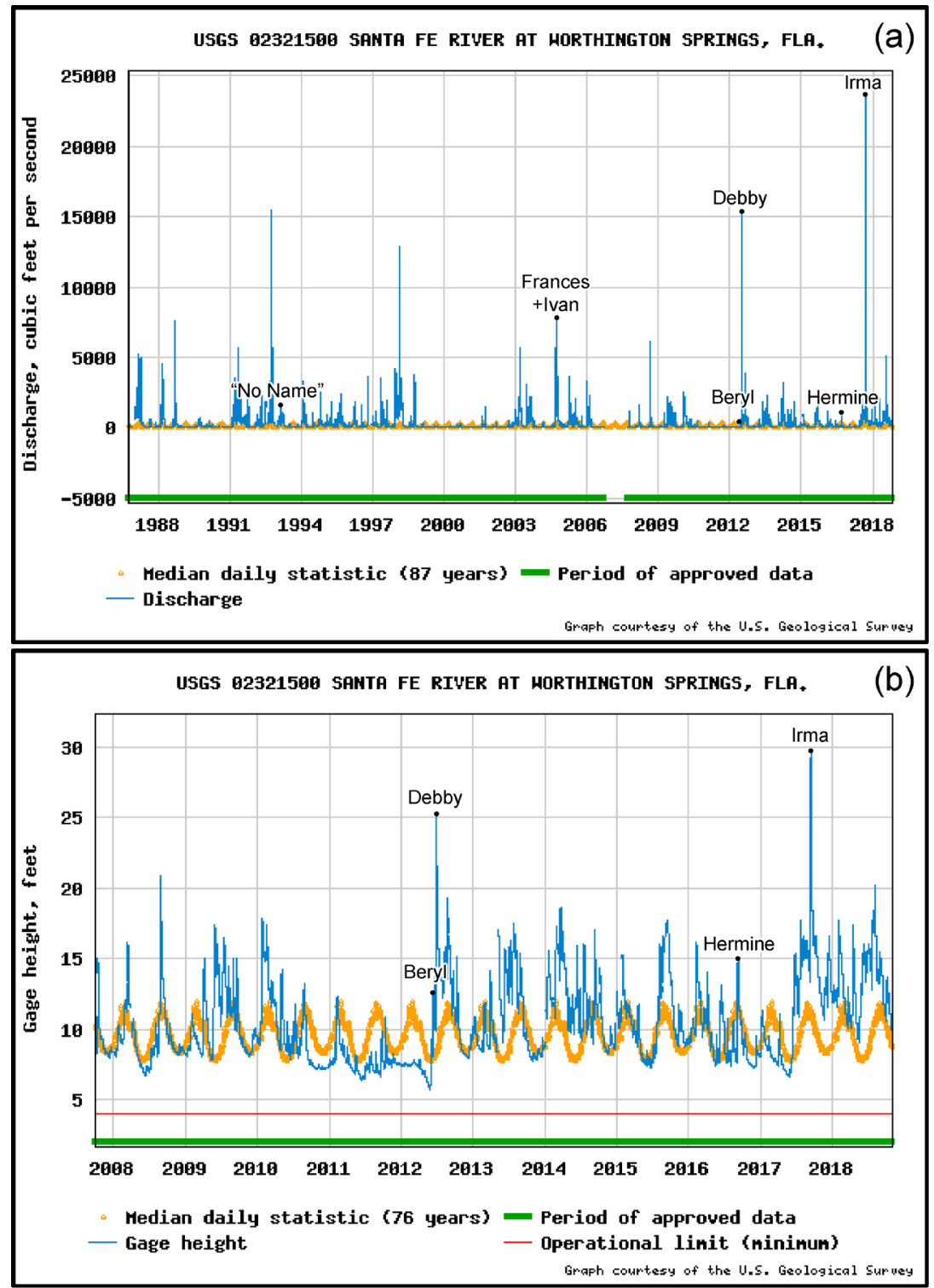

Figure 7. USGS graphs for the Santa Fe River at Worthington Springs gage station of historical: (a) discharges from October 1, 1986 through 2018 and (b) gage heights from October 1, 2007 through 2018.

$9.0 \mathrm{~m}$ (29.5 ft), respectively, in 2017 during the approximate time of Hurricane Irma. Those recorded values exceeded the stream discharge and gage height of $430.4 \mathrm{~m}^{3} \sec ^{-1}\left(15,200 \mathrm{ft}^{3} \mathrm{sec}^{-1}\right)$ and $7.6 \mathrm{~m}(25 \mathrm{ft})$, respectively, in 2012 during the approximate time of Tropical Storm Debby.

Similar responses are shown in Figure 8(a) and Figure 8(b) for stream discharges from 1990-2018 and gage heights from 2007-2018, respectively, for the USGS graphs of the New River Near Lake Butler. Specifically, record stream discharge and gage height were $413.4 \mathrm{~m}^{3} \mathrm{sec}^{-1}\left(14,600 \mathrm{ft}^{3} \mathrm{sec}^{-1}\right)$ and $4.7 \mathrm{~m}(15.6$ $\mathrm{ft})$, respectively, in 2017 during the approximate time of Hurricane Irma. As was the case for the previous two USGS gage stations, those recorded values also exceeded the stream discharge and gage height of $311.5 \mathrm{~m}^{3} \mathrm{sec}^{-1}\left(11,000 \mathrm{ft}^{3} \mathrm{sec}^{-1}\right)$ 


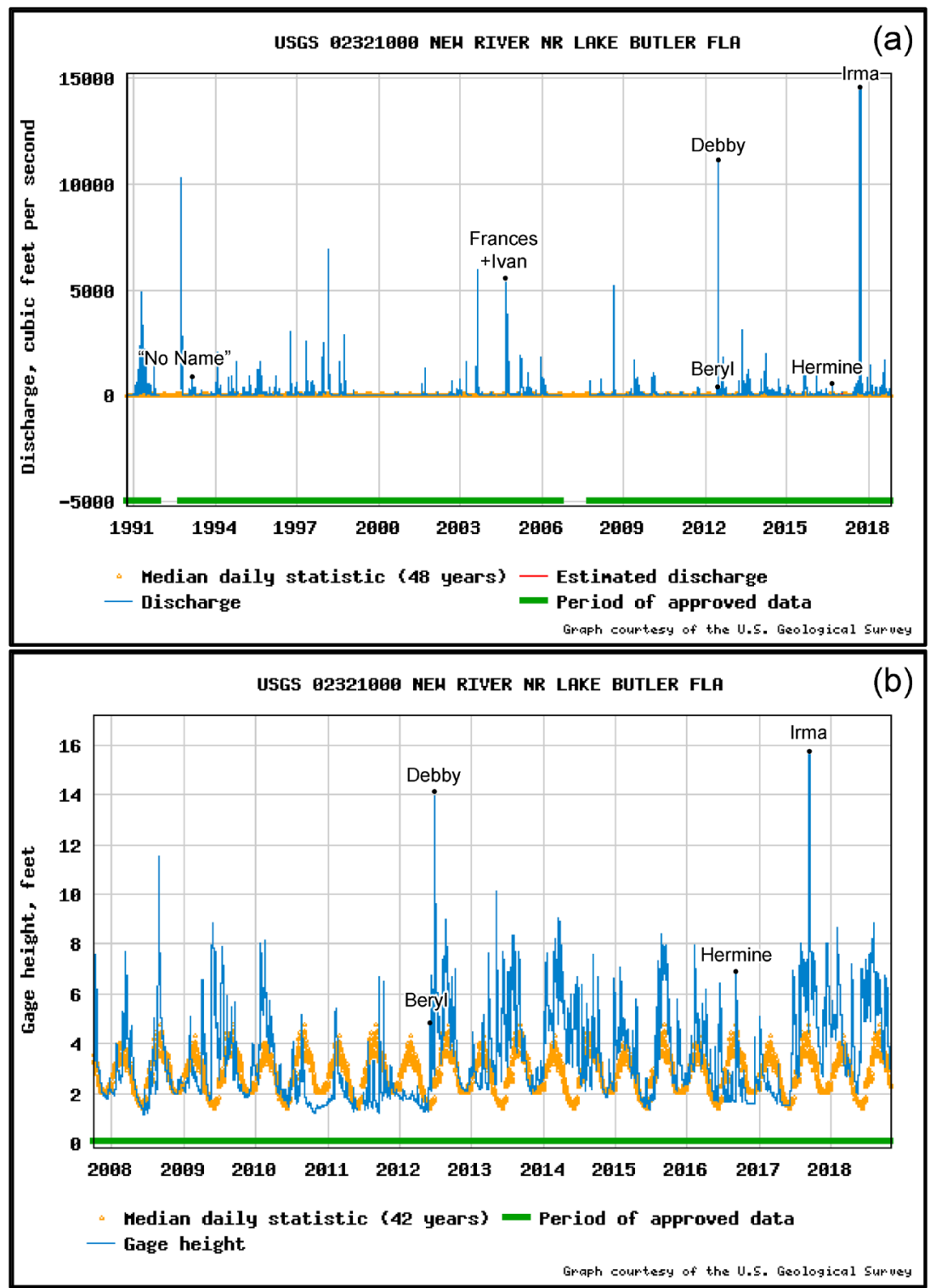

Figure 8. USGS graphs for the New River Near Lake Butler gage station of historical: (a) discharges from October 6, 1990 through 2018 and (b) gage heights from October 1, 2007 through 2018.

and $4.3 \mathrm{~m}$ (14 ft), respectively, in 2012 during the approximate time of Tropical Storm Debby.

Figure 9(a) and Figure 9(b) provide the USGS graphs for stream discharges from 2011-2018 and gage heights from 2010-2018, respectively, for the SFR at O'Leno State Park gage station. That gage station is located at the eastern (upstream) boundary of the park and east (upstream) of the park facilities and Buzzards Roost Prairie. During the time of Hurricane Irma in September 2017, stream discharge and gage height of $750.4 \mathrm{~m}^{3} \mathrm{sec}^{-1}\left(26,500 \mathrm{ft}^{3} \mathrm{sec}^{-1}\right)$ and $17.4 \mathrm{~m}$ $(57.1 \mathrm{ft})$, respectively, were reported for this gage station. Those recorded values also exceeded the stream discharge and gage height of $407.8 \mathrm{~m}^{3} \mathrm{sec}^{-1}\left(14,400 \mathrm{ft}^{3} \mathrm{sec}^{-1}\right)$ and $16.6 \mathrm{~m}$ (54.4 ft), respectively, in June 2012 during Tropical Storm Debby. 

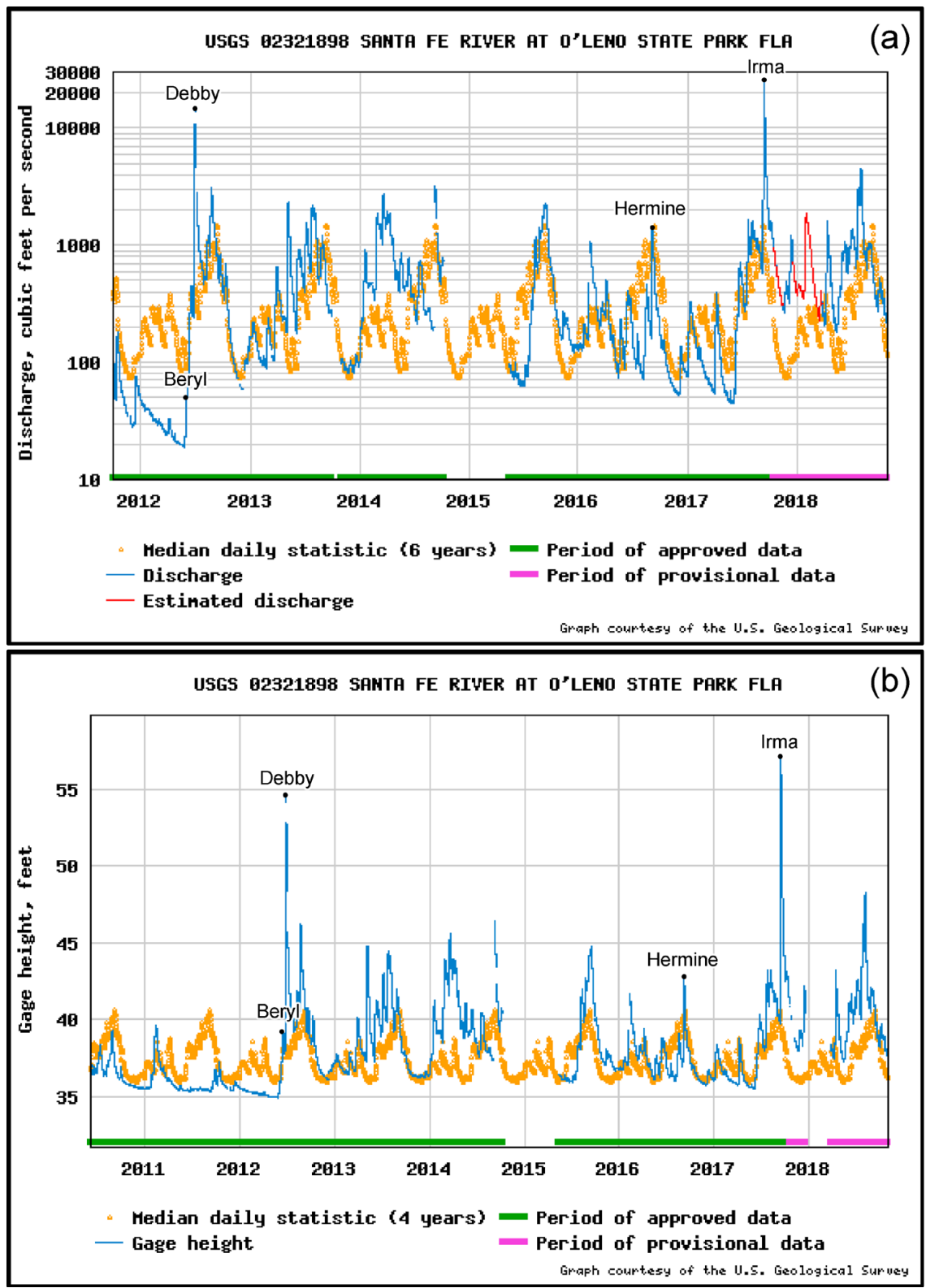

Figure 9. USGS graphs for the Santa Fe River at O'Leno State Park gage station of historical: (a) discharges from January 10, 2011 through 2018 and (b) gage heights from June 9, 2010 through 2018.

The shortest period of record for active USGS gages for the SFR is provided at the USGS gage for the SFR at River Rise Near High Springs. This gage station is located west (downstream) of the O'Leno State Park facilities and Buzzards Roost Prairie. The USGS graph for stream discharges and gage heights only extend from October 1, 2015 through 2018 (Figure 10). Peak stream discharge and gage height at that location were $529.5 \mathrm{~m}^{3} \mathrm{sec}^{-1}\left(18,700 \mathrm{ft}^{3} \mathrm{sec}^{-1}\right)$ and $6.4 \mathrm{~m}(21.1$ ft), respectively, in September 2017 during Hurricane Irma.

\subsubsection{Historical USGS Photographs of the Santa Fe River and New River}

The USGS NWIS website included historical USGS photographs of the SFR taken 


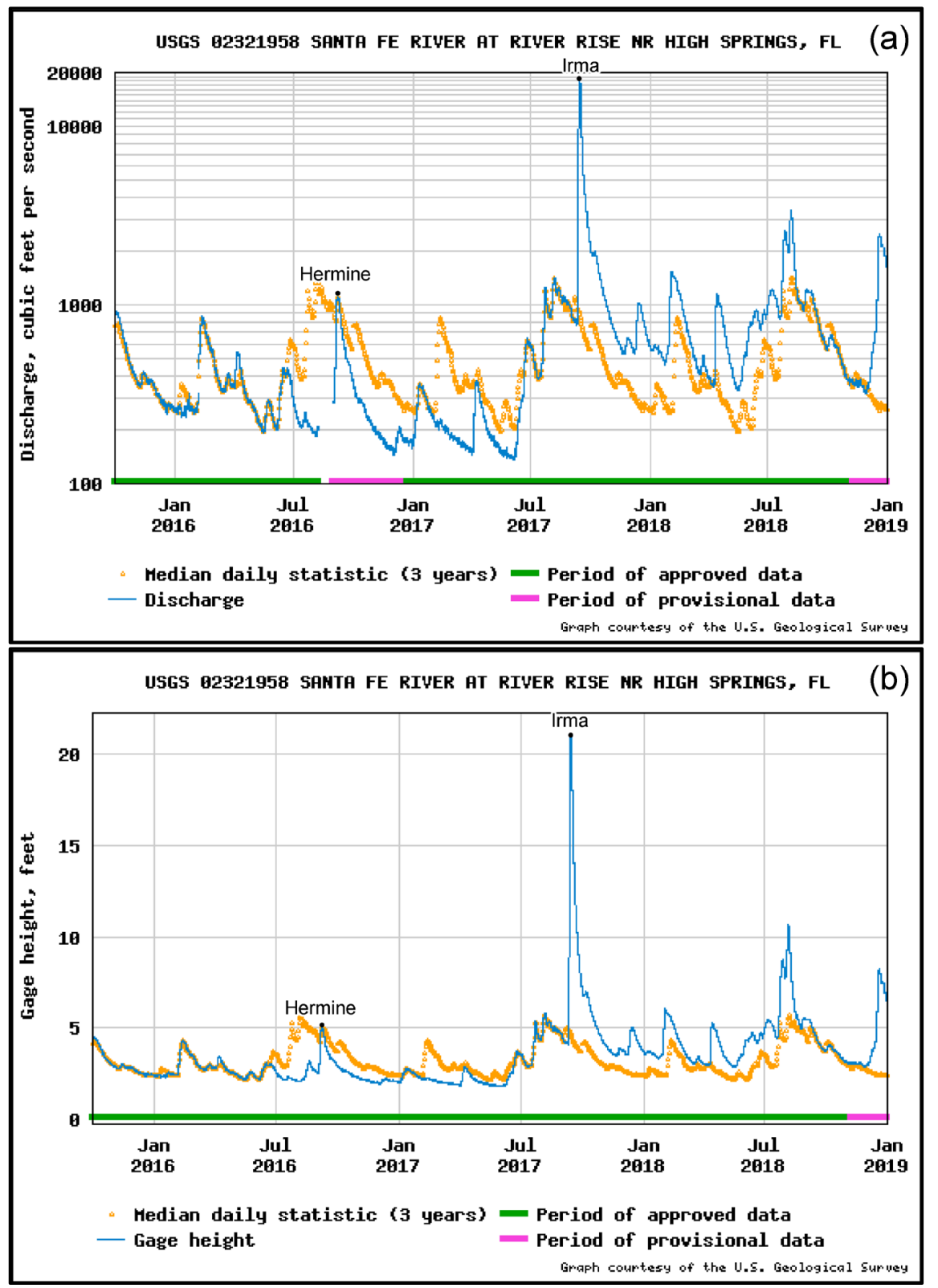

Figure 10. USGS graphs for the Santa Fe River at River Rise Near High Springs gage station of historical: (a) discharges from October 1, 2015 through 2018 and (b) gage heights from October 1, 2015 through 2018.

on December 20, 2006 and April 23, 2008 at the SFR at Worthington Springs gage station (Figure 11(a) and Figure 11(b), respectively). The NWIS website also included historical USGS photographs of the New River Near Lake Butler gage station taken on May 30, 2007 (Figure 11(c)). All three of these historical photographs show multiple dead trees associated with those sections of the SFR and New River. Figure 11(a) and Figure 11(c) show dead trees that fell across the stream channel. No reports could be found of those dead trees resulting in flooding upstream of those gage stations during those periods because those trees were impeding the flow of flood waters, including during Tropical Storms 

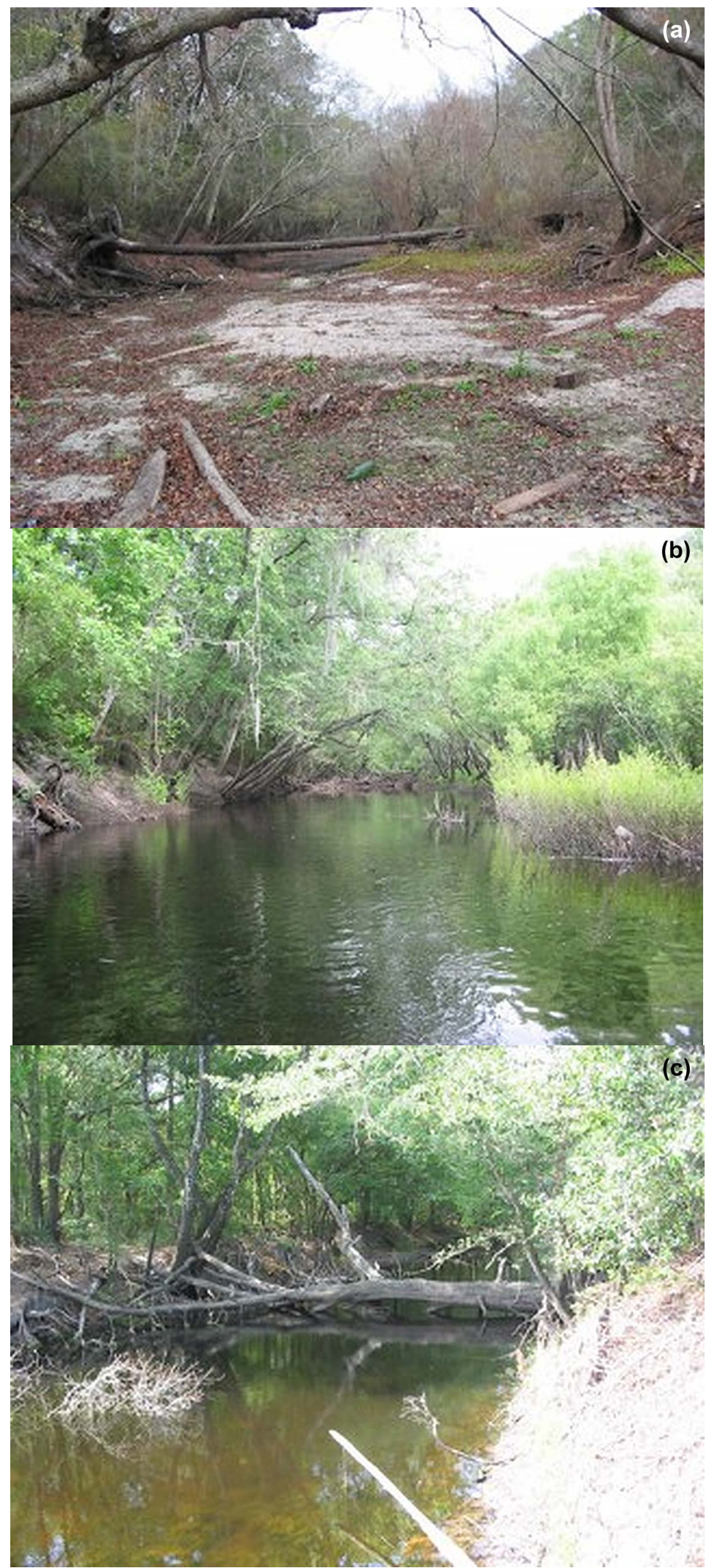

Figure 11. Historical USGS photographs of (a) Santa Fe River at Worthington Springs on December 20, 2006; (b) Santa Fe River at Worthington Springs on April 23, 2008; and (c) New River Near Lake Butler on May 30, 2007. 
Beryl and Debby in 2012, and Hurricane Irma in 2017. The dead trees associated with the SFR and New River shown in Figure 11 provide evidence of some other cause for tree deaths in the SFR Basin that pre-dated Hurricane Irma in 2017. Additionally, the precipitation record (Figure 3(a)), as well as the dry stream channel and surrounding vegetation in the USGS photograph of the SFR at Worthington Springs on December 20, 2006 (Figure 11(a)) suggest that lack of precipitation was not the cause of that dry stream channel.

\subsection{Discharges of Industrial Wastewater from Groundwater Withdrawals and Mining by Chemours/DuPont}

According to FDEP (personal communication, J. Martin 1/19), FDEP began NPDES regulation of existing discharges of industrial wastewater from groundwater withdrawals and mining of the Florida Trail Ridge by Chemours/DuPont in Clay County in approximately 1996. Prior to 1996, those discharges from the DuPont Florida Trail Ridge mining occurred under the original NPDES permit issued and regulated by the Region 4 Office of the US Environmental Protection Agency (USEPA). Expansion of that mining to Bradford County occurred in approximately 1999. Paul Still, Supervisor of the Bradford Soil and Water Conservation District, provided images, other supporting scientific data and documents, and personal observations in the formal complaint he filed with the Bradford County Board of Commissioners on June 16, 2016, and with the FDEP in the administrative review as evidence of Chemours' non-compliance with the NPDES permit issued by FDEP and Chemours' non-compliance with Bradford County's environmental regulations. Those scientific documents, data, and observations, accepted as evidence in the administrative review of Chemours' NPDES permit, included flooding being caused in Bradford County as a result of those Trail Ridge mining operations and discharges (P. Still, unpublished public records). Those Florida Trail Ridge mining operations have been renewed repeatedly, as permits issued to Chemours/DuPont by FDEP in both Baker and Bradford Counties, north and east, respectively, of the SFR and its tributaries. Therefore, those mining operations were considered as a contributing factor to the extensive flooding associated with Hurricane Irma in the SFR Basin.

\subsubsection{Chemours FDEP Permits for Discharges of Industrial Wastewater from Groundwater Withdrawals and Mining}

The FDEP permitted discharges of " 40 million gallons a day" (MGD) of heavy mineral mining wastewater from the Chemours/DuPont Trail Ridge Mining operation to tributaries of the SFR in the NPDES for Bradford County are described in the revised FDEP NPDES permit effective on June 29, 2017 (unpublished document prepared by the FDEP, 6/17). According to that revised FDEP NPDES permit, those discharges of heavy mineral mining wastewater have exceeded the permitted discharge volume, including discharge volumes of " 42.55 MGD" and with a maximum heavy mineral mining wastewater discharge of “55.3 MGD during tropical storm Debbie” [sic]. Tropical Storm Debby repeat- 
edly is referenced as "tropical storm Debbie" by FDEP and other agencies.

Separate FDEP permits for Chemours mining wastewater ponds in adjacent Baker County appear to authorize additional discharges of heavy mineral mining wastewater to the New River Swamp from at least the two southern Chemours discharge points identified in the FDEP permit for the Baker County Chemours Trail Ridge mine wastewater ponds. The New River Swamp wetlands are the headwaters of another SFR tributary, the New River, which is designated as critical habitat for the federally endangered oval pigtoe mussel (Pleurobema pyriforme). The historical precipitation data do not support the pattern of flooding associated with Hurricane Irma, or the reported increasing extent and magnitude of flooding in the SFR Basin from storms since Hurricane Dora and particularly during the five years preceding Hurricane Irma. The magnitude of discharged heavy mineral mining wastewater from Trail Ridge mining operations, combined with the self-reporting of those discharges, suggest that those discharges and extensive mining and groundwater withdrawals in Baker, Bradford, Clay, and Duval Counties have contributed to the record flooding of the SFR at the Worthington Springs location, as well as to the flooding and tree fall in the SFR Basin downstream of the Chemours/DuPont Trail Ridge discharge locations for heavy mineral mining wastewater.

Knowledge of the coding system for NPDES permits issued by FDEP is required to understand the history and magnitude of multiple heavy mineral mining wastewater discharges for Chemours'/Dupont's Trail Ridge mining in multiple Florida counties. Michelle Neeley, who provides permit assistance for FDEP's Northeast District Office, explained that the file numbers for the FDEP Chemours Trail Ridge permits for discharges of heavy mineral mining wastewater in Baker and Bradford Counties are FL0435490-007-IW3S,

FL0435490-009-IW3S, and FL0000051-012-IW3S, respectively. The group of three numbers in each file number that follows the permit number (i.e., 007, 009, and 012 , respectively) indicates the number of modifications to the original permit. The IW abbreviation in the file number indicates an "industrial wastewater" permit, and the number following that abbreviation is the number of permit revisions (personal communication, M. Neeley, 12/18).

The FDEP Chemours permit for discharges of heavy mineral mining wastewater in Baker County originally was issued on February 23, 2006. The FDEP Chemours permit for discharges of heavy mineral mining wastewater in Bradford County was "a revision for a name change to their incorporation status but it is still part of the same original permit that was originally issued in 2006" (FDEP, personal communication, M. Neeley 12/18). The reference to permit modifications required for a change in "incorporation status" is confusing, considering that the permittee's name on the initial Trail Ridge permit from FDEP and the 2006 FDEP permit for Baker County was "E. I DuPont de Nemours \& Co". The name on the current FDEP permit is Chemours Company TT LLC. Those names are not corporations and "LLC" is the abbreviation for Limited 
Liability Companies. That information is relevant for attempts to identify additional permits under various company and LLC names that would include additional impacts from the Trail Ridge mining, including impacts related to flooding downstream of those discharge locations. One of the advantages of Limited Liability Companies over corporation status is that LLC status prevents large monetary legal awards for equally large damages that can be caused to humans and the environment from activities such as mining. Some of the adverse impacts of mining are described in Bacchus (2006) and Bacchus et al. (2011).

According to Jeff Martin, Professional Engineer for FDEP's Northeast District the original FDEP Trail Ridge mining permit for Baker County was named the "DuPont North Maxville Expansion by the permittee because it was an expansion of the existing Trail Ridge mining in other counties, into Baker County. That Baker County Trail Ridge mining permit also includes the following information PA File No.: FL0435490-001-IW3S - PERMITTEE: E. I DuPont de Nemours \& Co." The first NPDES wastewater permit for FL000051001, Trail Ridge Mine, was issued by FDEP on October 18, 1996 and lists E.I. DuPont de Nemours \& Company as the Permittee. Prior to 1996, the USEPA issued NPDES permits throughout Florida (personal communication, J. Martin 1/19). In response to a FOIA request for a copy of the original NPDES permit issued to Dupont, the USEPA indicated there were no documents responsive to that request.

The information related to all of the referenced FDEP NPDES permits for Trail Ridge mining discharges by Chemours/Dupont, in addition to the NPDES permits originally issued by the USEPA for the Trail Ridge mining discharges by Dupont at least through 1996 would have provided valuable information regarding the impacts from long-term groundwater withdrawals associated with Trail Ridge mining by Chemours/Dupont on the premature decline and death of trees in at least Baker, Bradford, Clay, and Duval Counties. In the absence of that information, an estimate of "40 MGD" discharge authorized in the single FDEP NPDES permit for Bradford County discharges at the time that flooding occurred downstream of those discharges associated with Hurricane Irma can be considered as representative of groundwater withdrawals from the regional aquifer system in that area.

Even if that volume of groundwater withdrawals only extended from the period of time when the USEPA delegated NPDES permitting to FDEP (e.g., approximately 1996) to the present, that represents more than 20 years of environmental impacts from groundwater withdrawals of that magnitude. The significantly longer period of groundwater impacts would extend from 1949, when Dupont initiated Trail Ridge mining in that area, to the present (e.g. approximately 70 years). The “40 MGD” authorized as heavy mineral mining wastewater discharge in Bradford County by Chemours/Dupont also is approximately twice the "20.2 MGD" maximum authorized groundwater withdrawals under the CUP issued by the Southwest Florida Water Management District (SWFWD) for 
phosphate mining initiated in Hardee County in November 1977. Hardee County is within the Peace River Watershed of the regional Floridan aquifer system.

A study evaluating the magnitude and extent of groundwater alterations surrounding that mining operation in Hardee County (Peace River Watershed), using near-infrared (NIR) data from natural depressional wetlands, documented high mean NIR values consistent with hydroperiod-altered wetlands dominated by invasive plant species for 284 wetlands (50 and 60 percent total number and area, respectively), including some depressional wetlands more than $5 \mathrm{~km}(3.1$ mi) from study-area mines (Bacchus et al., 2011). Ground assessments in that study also included recording the presence, in or surrounding the wetlands, of any of the following indicators commonly associated with areas of hydroperiod alterations in the U.S. southeastern coastal plain: 1) premature tree mortality or decline; 2) poor crown condition; 3 ) insect and disease damage; 4) degraded soil conditions such as subsidence; 5) fragmentation of habitat; 6) invasive species (insects and plants); and 7) significant fire damage in fire-adapted ecosystems (Bacchus et al., 2011). The premature tree mortality and decline observed and described from our study were comparable to the premature tree mortality and decline associated with that Hardee County mining operation, where groundwater withdrawals were approximately half the volume of groundwater discharges from FDEP's single NPDES permit issued to Chemours/Dupont for discharges in Bradford County (Bacchus et al., 2011). The comparable premature death and decline associated with both mining sites provide support for the conclusion that Hurricane Irma was not the only cause of tree fall in Bradford County.

\subsubsection{Discharges of Heavy Mineral Mining Wastewater}

The FDEP NPDES permit for Bradford County, issued for the Chemours Trail Ridge mining operations, was accompanied by Administrative Order A O 185 NE, pursuant to paragraphs 403.088(2)(e) and (f), Florida Statutes. A specific requirement of the permit included compliance with that Administrative Order, but only required monitoring and reporting of groundwater levels and quality once every three months (i.e., quarterly). Not all of the 94 pages in that permit are numbered consecutively. Wastewater treatment is described on pdf page 4 of that 94-page permit, with excerpts included in our Table 1 . The reference to Keystone Heights, in Table 1 is because some of the natural lakes in that area (e.g., Brooklyn Lake) have experienced severe drawdowns or were completely dewatered during earlier Trail Ridge mining operations by DuPont in Clay County. Bernardes et al. (2014) include photographs and a more detailed discussion of that dewatering. The surfacewater discharge of heavy mineral mining wastewater at Outfall D-001 was described as "an existing 40.0 MGD daily permitted maximum" to Alligator Creek (WBID 3606), which is described as "Class III fresh surface water." The point of that discharge is shown in Figure 12(a). 
Table 1. Excerpts from the FDEP NPDES permit related to discharges of heavy mineral mining wastewater from Chemours'/DuPont's Trail Ridge mining operations.

\section{PDF Page}

Numbers

Quoted Excerpts

This heavy mineral mining wastewater treatment system provides acidification with ferric chloride, sulfuric acid, aluminum sulfate, or ferric sulfate to a pH between 3.0 and 3.5 standard units for flocculation of colloidal material followed by settling in a series of diked ponds, neutralization with hydrated lime to a $\mathrm{pH}$ between 6.0 to 8.5 , and additional settling with final discharge to Alligator Creek. Upon Department approval, polymer addition may be provided after neutralization for aluminum reduction prior to final discharge to Alligator Creek, at D-001, which flows west in Bradford County. Storm water and rainfall from the mined areas are also collected and treated as described above. The treatment train consists of the addition of barium chloride to the wastewater at the location where ferric chloride, aluminum sulfate and or ferric sulfate is added (prior to the humate settling ponds). A portion of the effluent is directed to the Southwest Quadrant Pond. The existing recycle line from D-001 was tapped and a pipeline was constructed to route approximately 400 gallons per minute (gpm) of the treated wastewater to an existing ditch which then discharges into the Southwest Quadrant Pond (location D-002) with eventual discharge into Blue Pond, which is the portion of Alligator Creek that flows south in Clay County. This rerouting of final effluent is the result of an effort by The Keystone Stakeholders to help improve lake water levels in the Keystone Heights area.

A review of the discharge flow through D-001 indicates that the 99th percentile is 42.55 MGD. Four times in the last permit cycle the flow exceeded $20 \mathrm{MGD}$, one time exceeding $30 \mathrm{MGD}$ (where the permit limit is $40 \mathrm{MGD}$ ) with the one-time maximum value of 55.3 MGD during Tropical storm Debbie [sic]. Because of the impacts of Tropical Storm Debby, Governor Rick Scott on June 25, 2012 signed Executive Order 12-140, declaring a statewide state of emergency. DEP issued an emergency authorization for Repairs, Replacement, Restoration and Certain Other Measures made Necessary by Tropical Storm Debbie [sic], OGC No. 12-1264 dated July

442 2012. Within the Emergency Area (Bradford, Clay and other counties) the requirements and effects of statutes and rules which conflict with the provisions of the Order were suspended to the extent necessary to implement this Order.

For the May 2013 rainfall event, the peak day discharge for D-001 was 29.8 MGD with May 2-May 6 rainfall totaling 7.71 inches. At this flow level, the Trailridge discharge accounted for 1.13\% of total flow to Alligator Creek Basin. The May 2013 event was the only documented abnormal event in this permit cycle. Looking at the monthly average flow for D-001, the 50th percentile is 3.0 MGD and the 95 th percentile is 10.45 MGD.

Alligator Creek has a contributing drainage area of 19.4 square miles. Low-flow frequency of the creek is following: $7 \mathrm{Q} 2=3.2 \mathrm{ft} 3 / \mathrm{s}$, $7 \mathrm{Q} 10=0.3 \mathrm{ft} 3 / \mathrm{s}, 30 \mathrm{Q} 2=8.0 \mathrm{ft} 3 / \mathrm{s} ; 30 \mathrm{Q} 10=1.1 \mathrm{ft} 3 / \mathrm{s}$. There is a SRWMD and USGS stage station at Alligator Creek below US 301 in Starke, Station ID: 02320734 (reference document: USGS Drainage Areas of Selected Surface water sites in Florida, Report 81-482, 1981).

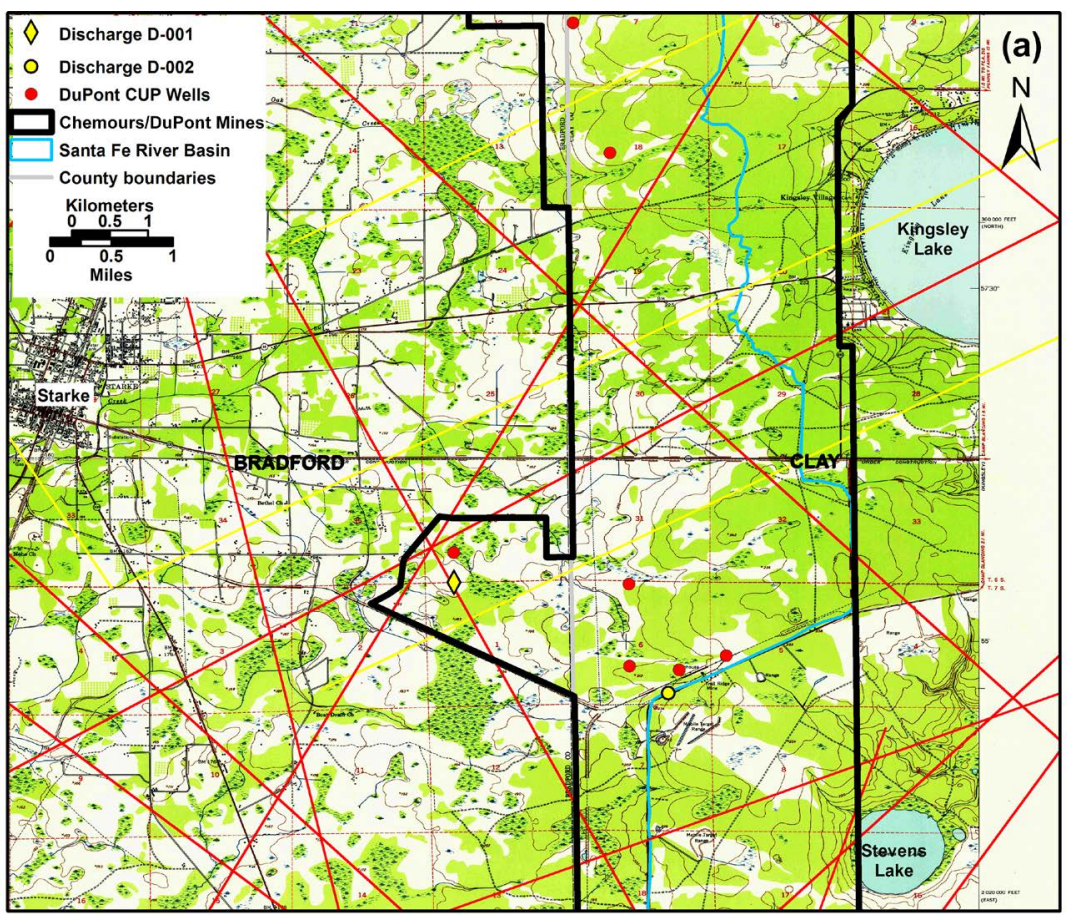




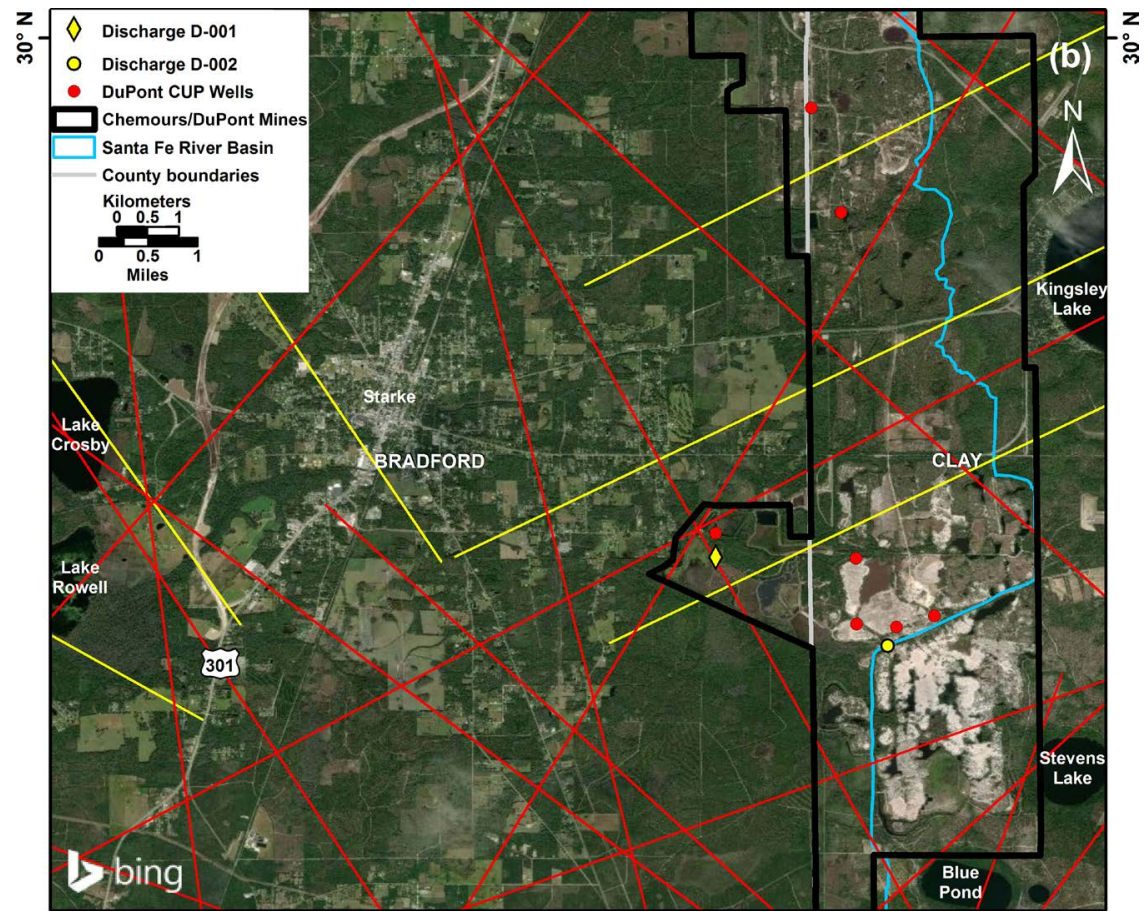

Figure 12. Location of partial southern boundaries of Trail Ridge mining operations established by DuPont in Bradford and Clay Counties, Florida, initial locations for consumptive use permit wells, two permitted discharge locations for heavy mineral mining wastewater, Santa Fe River Basin boundaries, and mapped fractures as shown in Figure 5, over the: (a) historical 1949 USGS 7.5 minute topographic basemap for Starke, Florida and (b) Bing 2018 aerial basemap.

The second existing discharge of heavy mineral mining wastewater, Outfall D-002, is at the Southwest Quadrant Pond, which then discharges to Blue Pond (WBID 2501). Blue Pond also is described as a "Class III fresh surface water". The point of discharge of heavy mineral mining wastewater for D-002 also is shown in Figure 12(a) and Figure 12(b).

Following the route of flow in Bradford County from the Chemours D-001 discharge point, ditches were evident east of Starke in the vicinity of Highways 230 and 16, and NE171st Street. Those ditches appeared to divert a portion of the D-001 discharge of heavy mineral mining wastewater from Alligator Creek, north into Water Oak Creek (Figure 13(a)). This discharge north to Alligator Creek, flowing behind homes on the west side of the Starke Golf and Country Club, should be investigated as the potential source of the severe flooding of those homes on more than one occasion. Additionally, because Water Oak Creek is a tributary of, and discharges to the New River, this discharge to the north should be investigated to determine the magnitude and extent of impacts to that designated critical habitat for the federally endangered oval pigtoe mussel.

Any of the Chemours Trail Ridge discharges of heavy mineral mining wastewater from D-001 that are diverted to the Water Oak Creek tributary of the New River would reduce Chemours' D-001 discharges of that mining wastewater to 


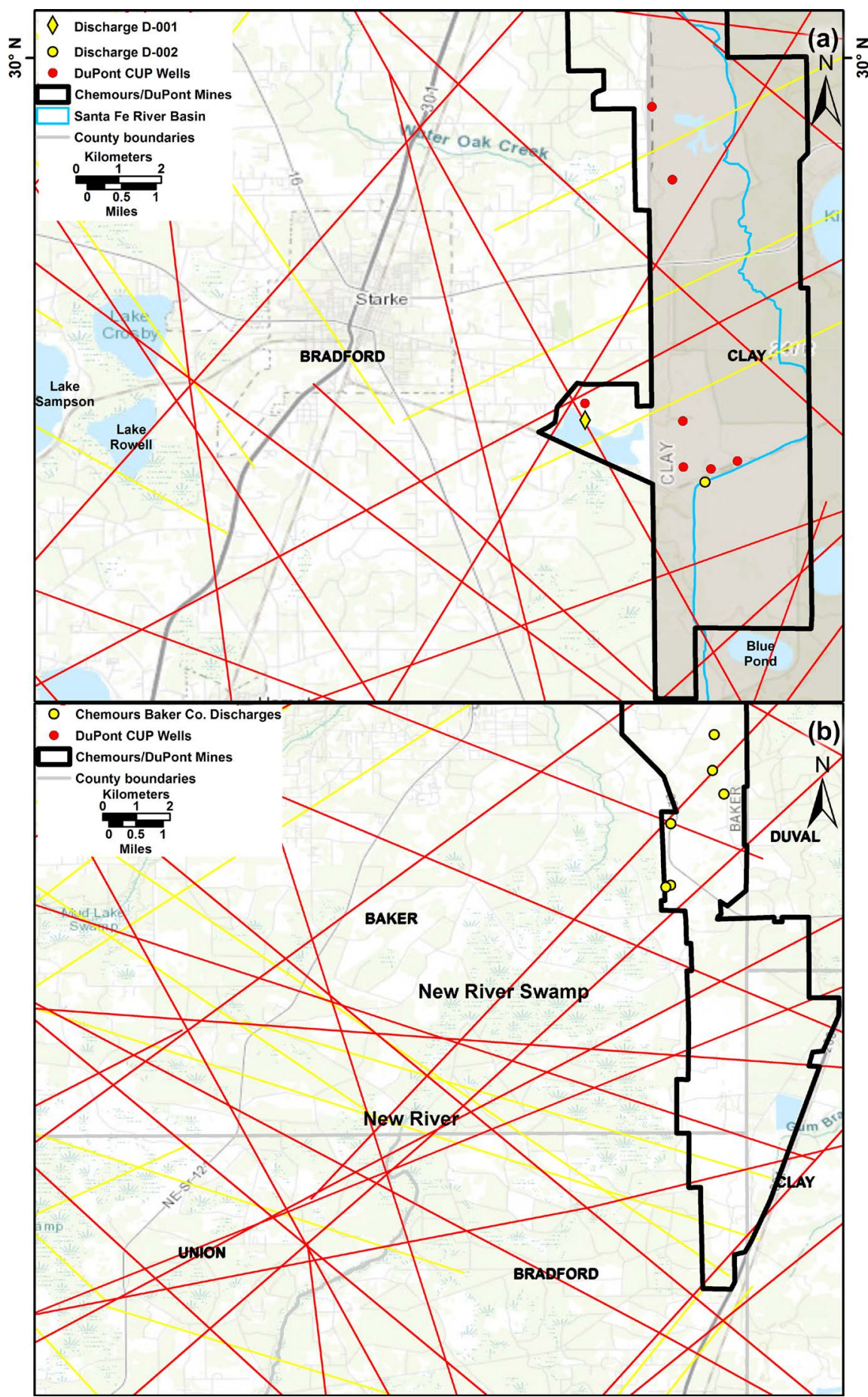

Figure 13. World topo imagery showing the locations of Trail Ridge mining operations established by DuPont and mapped fractures as shown in Figure 5, in proximity to: (a) Water Oak Creek near discharge locations for the southern mining boundaries in Bradford and Clay Counties, Florida, and (b) the New River Swamp and New River near discharge locations for the northern mining boundaries in Baker, Bradford, Clay, and Duval Counties, Florida.

Alligator Creek, Lake Rowell, Lake Sampson, and the Sampson River that flow into the SFR west of Graham. Those diverted discharges, however, would not 
reduce any flooding that may be related to those discharges in downstream areas of the SFR, such as in O'Leno State Park and Buzzard's Roost Prairie in Alachua and Columbia Counties, respectively. In fact, any diversions of heavy mineral mining wastewater in Bradford County north to Water Oak Creek, combined with Chemours discharges to the New River Swamp headwaters of the New River in Baker County (Figure 13(b)), simply would by-pass tributaries to the SFR in Bradford County and divert those combined Chemours' discharges, increasing flooding to downstream sections of the SFR in other counties (e.g., Alachua, Columbia, and Union Counties).

\subsection{Amendment to Fact Sheet for FDEP's Chemours NPDES Permit in Bradford County}

The FDEP NPDES permit for Chemours in Bradford County included an "Amendment to Fact Sheet". That Amendment states, "Sampling is conducted for the effluent discharge for outfall Group D-001. The same discharge can be directed to Monitoring Group D-002, so sampling for D-001 represents the discharge for D-002." The Amendment also indicated that Alligator Creek is classified as Class III fresh waters (WBID 3598C), with a designated use classification for recreation, propagation, and maintenance of a healthy, well-balanced population of fish and wildlife. Alligator Creek drains into Lake Rowell and, ultimately, into the SFR via the Sampson River. The Amendment also states that Alligator Creek was a small, intermittent stream, receiving seepage and overland flow from the area's mixed pine and hardwood forests before the development of the City of Starke, Florida. During subsequent decades, Alligator Creek was dredged several times prior to environmental regulation with the intent of draining areas within the City of Starke. That amendment claims that restoration of that stream is needed to improve wetland functions in the Alligator Creek floodplain and protect this system from continued erosion and degradation. That amendment also claimed that: 1) stream "restoration" was not done because it has been cost-prohibitive and 2) dredging events destabilized the stream in many locations "causing continued erosion and water quality problems."

\subsubsection{Indicators of Long-Term Anthropogenic Hydroperiod Alterations}

The photographs in Figures 14(a)-(c) illustrate the narrow, but deeply incised dredged channel of Alligator Creek in Starke, Florida. Figure 14(a) and Figure 14(c) show the bridge on the east side of Highway 301 at 900 South Walnut Street, while Figure 14(b) was taken from that bridge. The concrete swale shown in Figure 14(a) directs untreated stormwater directly from Highway 301 and surrounding paved areas into Alligator Creek. The textured end of that concrete swale at Alligator Creek is shown in Figure 14(b). The Sports Utility Vehicle (SUV) shown on the left (north) side of Figure 14(b) provides an approximate scale suggesting that the dredged depth from the top of the Alligator Creek banks to the surface of the water exceeds $9 \mathrm{~m}(29.5 \mathrm{ft})$. That extreme depth and apparently shallow water, shown at the base of the concrete bridge in Figure 14(a), 
strongly suggest that the surficial aquifer has been lowered to approximately the base of that deeply dredged stream for an extensive area surrounding Alligator
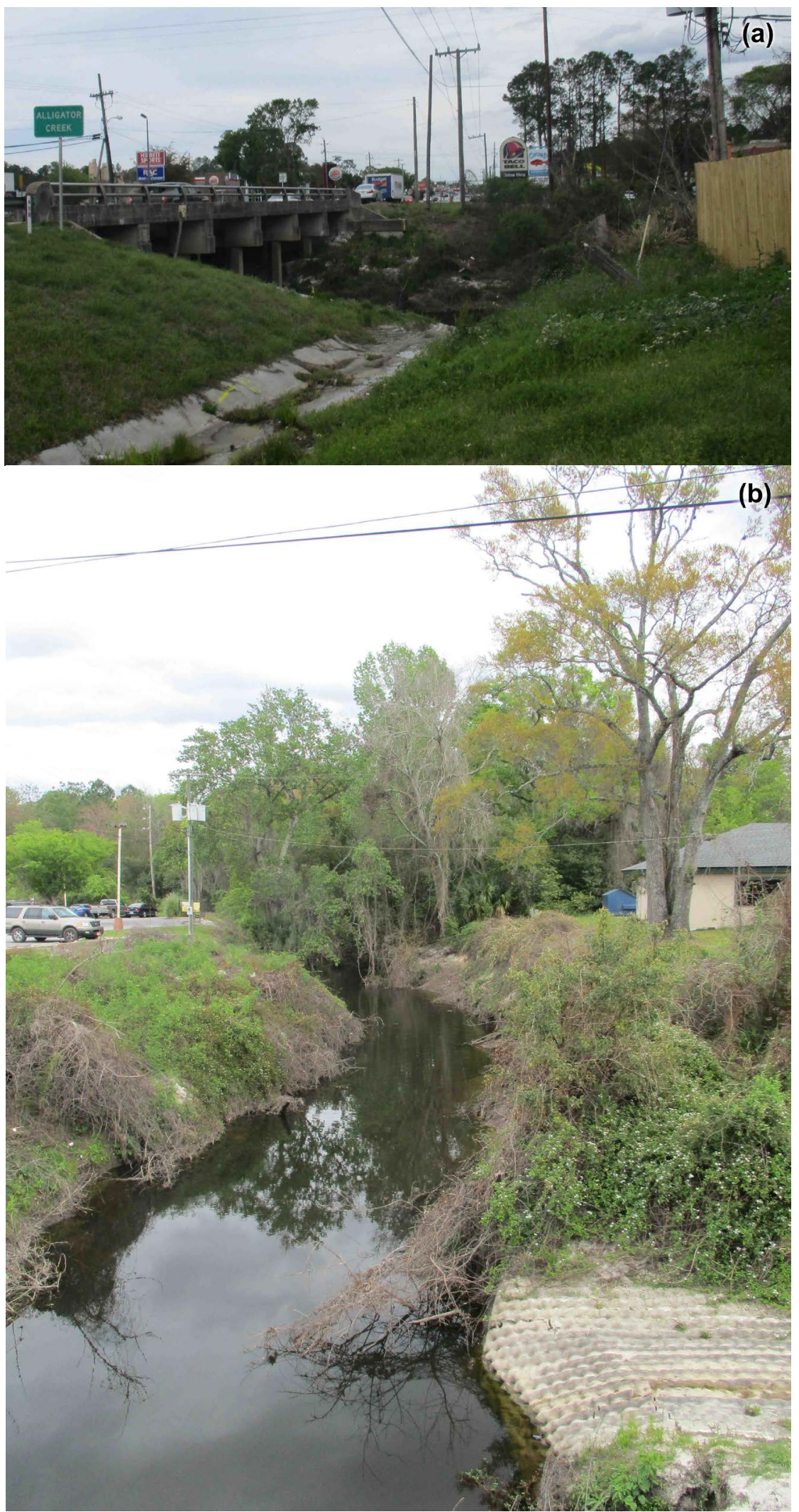


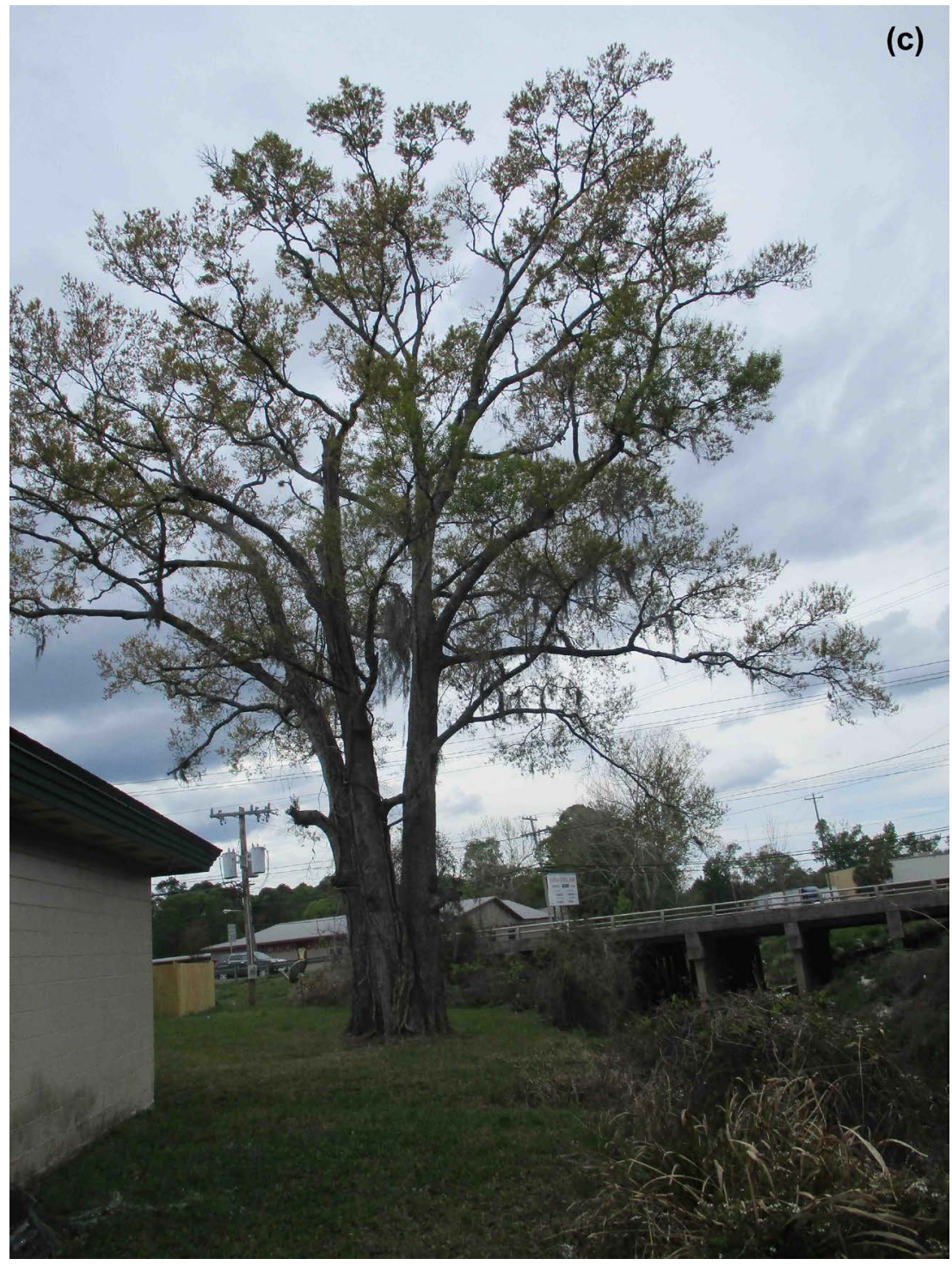

Figure 14. Photographs of the dredged channel of Alligator Creek taken in the vicinity of the Highway 301/Temple Avenue bridge in Starke, Florida on March 11, 2018, facing: (a) north; (b) east; and (c) west.

Creek. Dewatering the surficial aquifer greatly decreases or completely eliminates baseflow of ground water required to maintain natural flow in the stream during periods of low rainfall.

In addition to providing information about the impacts to the surficial aquifer, Figure 14(b) and Figure 14(c) also provide information about the impacts of that hydroperiod alteration on native and invasive plants. Native wetland vegetation has been replaced by impenetrable thickets of brambles (Rubus sp.) on the steep banks of the dredged channel of Alligator Creek. These figures also show the premature decline in the native trees along the south bank of Alligator Creek (Figure 14(b), right side and Figure 14(c), left side). The photographs in Figures 15(a)-(c), also taken on the south bank of Alligator Creek on March 11, 2018, show more extensive evidence of premature decline of native trees, in 

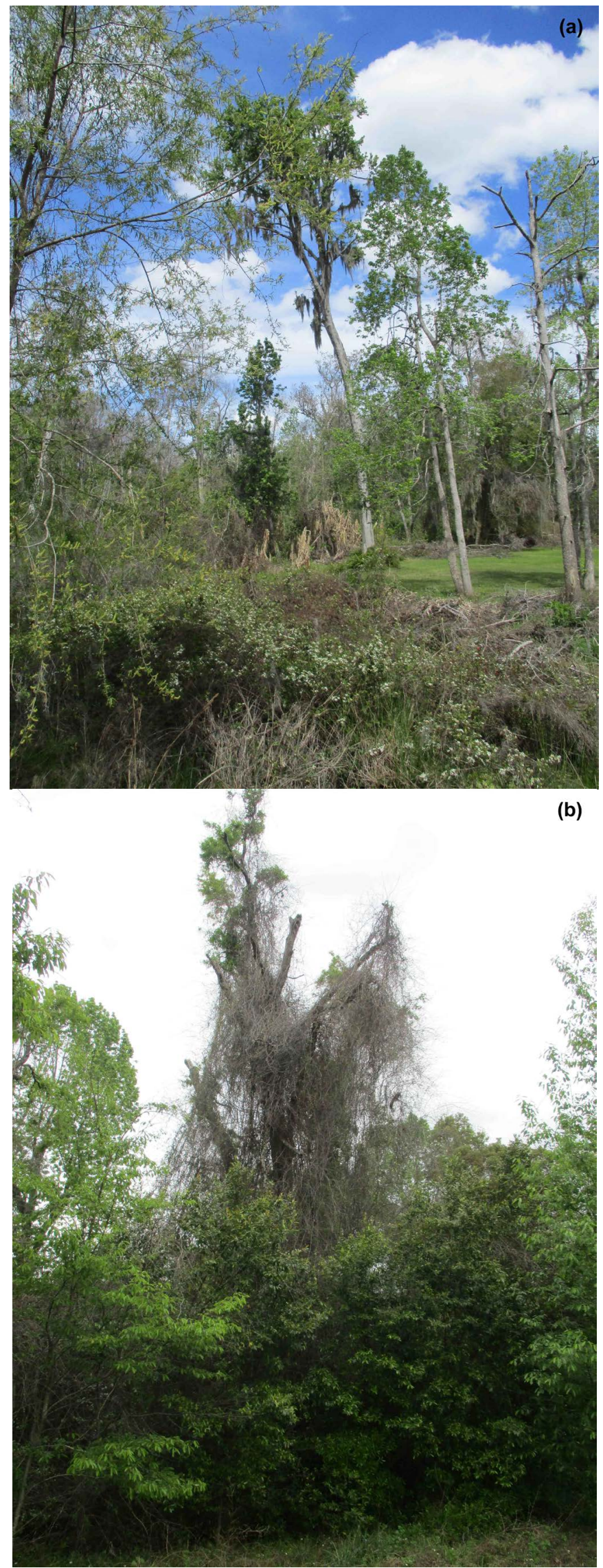


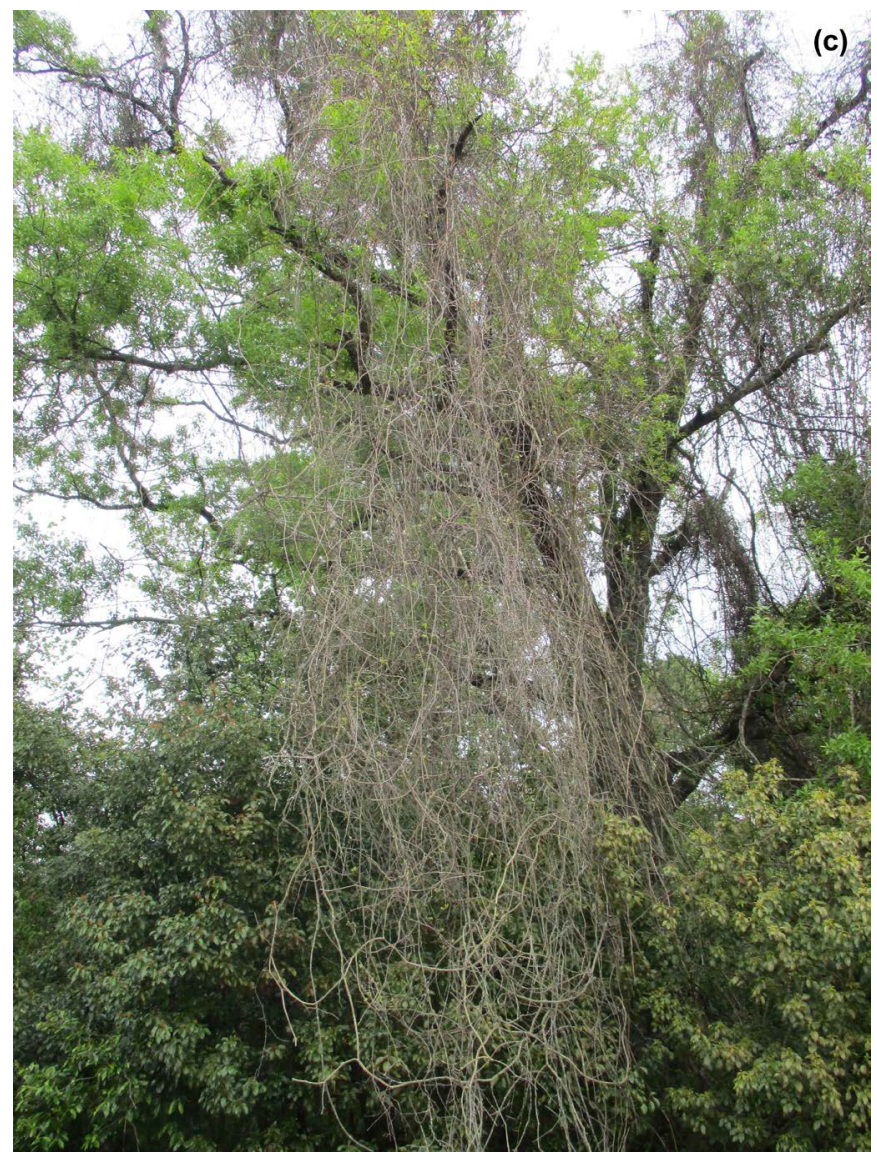

Figure 15. Photographs taken on the same date and general location of dredged channel of Alligator Creek as Figure 14, on the south bank, showing additional dead and prematurely declining native trees, and invasive trees, vines, and brambles.

addition to invasive trees, vines, and brambles. The extremely sparse canopy and dense Spanish moss in the canopy of native trees (Figure 15(a)) is a premature-decline indicator of chronic water stress from alterations of natural hydroperiods that have extended for significantly longer than the approximately six months since Hurricane Irma. The aggressive growth of woody vines that cover tree canopies (Figure 15(b) and Figure 15(c)), as well as invasive tree species, such as the thick growth of camphor trees (Cinnamomum camphora) shown in the lower third of Figure 15(c), also are indicative of dewatered surficial aquifers from long-term alterations of natural hydroperiods. Additionally, the dead and near-dead trees shown in Figure 15(a) and Figure 15(c), respectively, also are typical in areas of chronic water stress due to alterations of natural hydroperiods.

Altered hydroperiods by dewatering the surficial aquifer prevent native trees and other native plants associated with streams in the southeastern US from essential access to normal groundwater levels in the surficial aquifer during periods of low rainfall, including during the dry season. This type of anthropogenic alteration of natural hydroperiods commonly is caused by mining and results in the premature death and decline of both wetland and upland native trees and 
other native vegetation (Bacchus, 2006), in addition to destructive wildfires (Bacchus, 2007). The root systems of these native trees also play an important role in preventing erosion of stream banks. Consequently, the premature decline and death of those trees contribute to increasing sediment load in streams, such as Alligator Creek, even in the absence of any sediment-laden discharges of heavy mineral mining wastewater from the Trail Ridge mining operations. Additionally, Figure 12(a) shows the location of the eastern boundary of Chemours Trail Ridge Mining, oriented north/south near the western boundaries of Kingsley Lake and Stevens Lake in Clay County, and the western boundary of Chemours Trail Ridge Mining, oriented north/south along the eastern Bradford County line and extending into Bradford County. The 1949 Starke, Florida USGS topographic quadrangle basemap for Figure 12(a) displays some of the historical wetlands that have been destroyed by the Chemours Trail Ridge Mining in Bradford and Clay Counties, with the standard wetland symbol over dark green representing areas that were mapped as wetlands in 1949.

Also shown in Figure 12 is the location of the CUP groundwater withdrawal well due north of the D-001 Chemours' discharge of heavy mineral mining wastewater to Alligator Creek, in the west extension of the Chemours/DuPont Trail Ridge mining boundaries into Bradford County and northwest of the D-002 Chemours' discharge location in adjacent Clay County. That CUP withdrawal well is located within the depressional wetlands comprising the headwater of Alligator Creek and also is located in proximity to the intersection of three fractures mapped by FDOT (1973) and shown as red diagonal lines in Figure 12.

Consequently, the groundwater withdrawal impacts from that CUP well, initially constructed under the CUP issued for DuPont's Trail Ridge mining, would be expected to extend throughout those fractures, dewatering additional wetlands, streams, natural lakes, and uplands in at least Bradford, Clay, Duval, and Baker Counties. The four additional CUP wells in Clay County, southeast of the Bradford County CUP well and in the vicinity of the D-002 discharge location of heavy mineral mining wastewater (northwest of Stevens Lake), combined with the additional CUP wells to the north, initially constructed under the CUP issued for DuPont's Trail Ridge mining, exacerbate those alterations of natural hydroperiods in wetlands, streams, natural lakes, and uplands. These well-documented responses to anthropogenic alterations of natural hydroperiods suggest that the description of the proposed "floodplain restoration project" in the FDEP Chemours' NPDES Amendment, with excerpts included in our Table 2, will not accomplish those stated results. Not all of the 94 pages in that permit are numbered consecutively. The "floodplain restoration project" is described on pdf page 46 of that permit.

Figure 12(b) includes the 2018 Bing aerial basemap with the same boundaries of the Chemours Trail Ridge Mining area, as well as the locations of seven CUP groundwater withdrawal wells and D-001 and D-002 discharge locations of heavy mineral mining wastewater, in addition to the fractures mapped by FDOT 
Table 2. Excerpts from the FDEP NPDES permit with no supporting documentation.

PDF Page
Numbers

During the days of September 2 through September 4, 2016, Governor Scott issued a State of Emergency for Bradford county, Executive Order 16-205, signed August 31, 2016, requirements and effects of statutes and rules which conflict with the provisions of this Order are suspended to the extent necessary to implement this Order. In response to the order, a site inspection was conducted

47 on September 7 to view the West Levee system at Trailridge. The system was stable with no discharge occurring at this location and no evidence of a breach in the berm. The pump system was operating as normal. For the days of September 1-September 5, the Alligator Creek stage level at US 301 stream gage was reviewed and the Trailridge discharge for those days are [sic] listed in Table 4. The maximum day of discharge was September 3 at 7.34 MGD which is less than $0.5 \%$ of the total basin flow to Alligator Creek.

Paragrapgh [sic] 6 is copied here:

6. The Department finds that

- The Chemours Company TT LLC needs permission to discharge wastewater into the waters within the state for a period of time necessary to complete research, planning, construction, installation, or operation of an approved and final control system;

- There is [sic] no present, reasonable, alternative means of disposing of the wastewater other than by discharging it into waters of the state;

$61-62$

- The granting of a discharge permit will be in the public interest;

- The discharge will not be unreasonably destructive to the quality of the receiving waters.

To reduce the volume and iron loading into Alligator Creek the NPDES permit should require that the discharges be split equally between D001 and D002. The discharge limit for D001 should be set at 20 MGD to reduce the total iron discharged into Alligator Creek and the Sampson Basin.

(1973) and Vernon (1951). Figure 12(a) and Figure 12(b) also show the 2018 surface conditions within the boundaries of the Chemours Trail Ridge Mining area, in proximity to Starke and some of the remaining natural features. Figure 12(b) also extends further south than the Starke USGS topographic map, including not only Kingsley and Stevens Lakes along the east boundary of the figure, but also Blue Pond in the southeast corner of the figure. Blue Pond receives the heavy mineral mining wastewater discharged at D-002, as the alternate discharge location for D-001. After flowing through Blue Pond, any wastewater discharged from D-002 flows south, through Lake Lowery, Magnolia Lake, Brooklyn Lake, and Lake Geneva, along the eastern side of the Santa Fe Swamp. Those lakes are located along the western boundary of Clay County, and the Santa Fe Swamp.

Figures 11(a)-(c) in Bernardes et al. (2014) illustrate the severity of the dewatering of Brooklyn Lake, which was one of the most severely dewatered lakes in the vicinity of the Trail Ridge mining area during that study. The dewatered portion of Brooklyn Lake shown in Figure 11(a) and Figure 11(b) in Bernardes et al. (2014) also is known as Brooklyn Bay. The entire area in Figure 11(c) from Bernardes et al. (2014), between the shrubby vegetation in the foreground of that photograph and the tree line in the background of that photograph, is the com- 
pletely dry lake bottom of Brooklyn Lake on the northwest side of State Road 21, the opposite side of the road from Brooklyn Bay, in Keystone Heights. The bare, white, linear, sandy areas from the lower left corner to the approximate center of Figure 11(c) reportedly were made by all-terrain vehicles (ATVs) traveling back and forth from one side of the dewatered lake to the other. The third co-author in Bernardes et al. (2014) also observed ATVs traveling along that linear, baresand area during the site inspections and ground-thruthing for that study.

The headwaters of the SFR, the Santa Fe Swamp, are located along the eastern boundary of Bradford County, but are not shown in Figure 12(a) or Figure 12(b). The western boundary of Figure 12(b) includes Lake Crosby to the north and Lake Rowell to the south. Alligator Creek flows into and through the east-central part of Lake Rowell, continuing to the west, through Lake Sampson and south into the Sampson River, a tributary of the SFR to the south. The FDEP Chemours' NPDES Amendment also included statements regarding the southern Alligator Creek in Bradford County, where Chemours' NPDES discharges of heavy mineral mining wastewater are occurring and the characteristics of those discharges at D-001. Examples of those statements from pdf pages 44 and 46 are included in Table 1.

\subsubsection{State of Emergency Declaration for Hurricane Hermine}

The Amendment to Fact Sheet also addressed Hurricane Hermine. According to NOAA (2016) the ragged eye of Hurricane Hermine did not become evident on visible imagery until September 1, 2016 and hurricane intensity was not reached until 1800 UTC, as Hurricane Hermine was centered about 213 km (115 n mi) south-southwest of Apalachicola, Florida. Hurricane Hermine strengthened to a peak intensity of "70 kt by 0000 UTC 2 September." "Hermine maintained that intensity until landfall along the Florida Big Bend coast just east of St. Marks, Florida, at 0530 UTC 2 September" (NOAA, 2016). St. Marks is located in Wakulla County, Florida, approximately $194 \mathrm{~km}(122 \mathrm{mi})$ west of Bradford County as a straight-line distance. According to that FDEP Chemours' NPDES Amendment, a "State of Emergency for Bradford county, Executive Order 16-205" was signed August 31, 2016 by Florida Governor Rick Scott. The NOAA account of Hurricane Hermine could be sufficient to declare a State of Emergency signed by the Florida Governor on August 31, 2016, for the predicted path of a hurricane and evacuation orders, but could not be used for determining damage in a county before that hurricane made landfall approximately $200 \mathrm{~km}$ away and before residents in that area began experiencing hurricane-related winds or precipitation.

Residents in the vicinity of the SFR Basin have reported extreme high water conditions in the SFR and SFR tributaries preceding hurricanes, tropical storms, and during periods of no rainfall in 2018. The information included on pdf page 47 of Chemours' FDEP NPDES permit for Bradford County regarding that State of Emergency declaration (Table 2) appears to presume that Chemours did not make significant discharges of heavy mineral mining wastewater immediately prior to the landfall of Hurricane Hermine to prevent berm breaches. That ap- 
proach of pre-emptive releases of contaminated water would be similar to the environmentally harmful releases (i.e., discharges) of contaminated water from Lake Okeechobee in south Florida prior to hurricanes. No documentation was found to substantiate that pre-emptive releases of contaminated water were not made from Chemours' discharge locations prior to anticipated increases in precipitation from hurricanes and tropical storms, including those addressed in our study.

\subsubsection{FDEP Sampling, Inspections, and Results}

The Amendment also stated that the "discharge to D-002 is 'report' only, and the quantity of the discharge of heavy mineral mining wastewater is not limited unless it is restricted by requirements from other regulatory authorities." Because Chemours is allowed to divert unlimited Trail Ridge heavy mineral mining wastewater from D-001 to D-002 and because FDEP does not collect or analyze samples of heavy mineral mining wastewater from the D-002 location to Blue Pond, south through a series of lakes to dewatered Brooklyn Lake, those discharges from D-002 could be significantly more contaminated than Chemours discharges of heavy mineral mining wastewater at other discharge locations. The Amendment to FDEP's Chemours NPDES permit for Bradford County also included the statements on PDF page 51 (Table 3), confirming that FDEP was not able to analyze samples for Radium 228 and that the sampling protocol was compromised by blank sample containers that were contaminated.

Table 3. Excerpts from the FDEP NPDES permit describing FDEP sampling, inspections, results, and other limitations related to Chemours'/DuPont's Trail Ridge mining operations.

PDF Page
Numbers

Effluent grab samples for toxicity testing were collected on September 8, 10, and 12, 2014. Effluent grab samples for biological and chemical analyses for this facility were collected on September 8, 2014. All samples were collected from the EFF-01 NPDES sampling point for Outfall D-001.

- The total ammonia concentration in the grab sample collected and preserved for chemical analysis was $0.04 \mathrm{mg} \mathrm{N} / \mathrm{L}$. Based on the $\mathrm{pH}$, salinity, and temperature of the effluent as collected, the calculated unionized ammonia concentration was $<0.02 \mathrm{mg} / \mathrm{L}$.

- The effluent's iron (1080 ug/L) exceeded Class III Fresh Water Criteria and the permitted limit. Turbidity and alkalinity were detected in the effluent at levels that comply with Class III Fresh Water Quality Criteria (62-302.530, F.A.C.) and/or permitted limits. Total suspended solids, fluoride, arsenic, total chromium and nickel were detected between the laboratory method detection limits (MDL) and practical quantitation limits (PQL).

- The overflow lab did not have enough sample volume to perform QC and analyze Radium 228, therefore, no Radium 228 results were reported.

- Nitrate + nitrite was detected in the field blank.

DEP Mining and Minerals Regulation Program staff conducted an inspection of the Chemours Trail Ridge Mine on October 27, 2015, including the West Levee and the portion of the SRWMD's West Ridge Property located within the Trail Ridge Mine, and found no evidence of uncontrolled discharges of surface water to adjacent properties or offsite sedimentation impacts. SRWMD have found no evidence that the surface water channel on the West Ridge property has caused sedimentation impacts or offsite flooding on adjacent or downstream properties in Bradford County. 


\section{Continued}

Flow limits were increased in 2011 from 30 to 40 MGD with no apparent documentation about the impacts this increase would have on flooding of homes and properties. Tropical Storm Debbie [sic] caused flooding in the Starke Country Club area the closest residential area downstream of the Chemours D001 discharge point. At the end of June 2012 Chemours' discharges were over the 40 MGD limit for 4 days with the highest daily discharge being 55.3 MG. Chemours flows likely added to the level and duration of flooding in the Alligator Creek and Sampson River Basins.

Discharges over the spillway at the south end of the West Levy that bypass the water treatment facility need to be addressed. These discharges have occurred on several occasion [sic] and need to be addressed in the current permit renewal. These discharges are releasing untreated mine contact water with high humate content.

The failure to control or address erosion from the mined areas that have not been reclaimed and the role the erosion plays as the source of humate in stormwater need to be addressed. Humate rich strata deposited during the dredge mining are eroding and causing very high humate levels in stormwater. The erosion problem needs to be addressed as a BMP to reduce or even eliminate the high levels of humate. The current conditions east of CR 225 in Bradford County on land owned by the SRWMD indicate that erosion BMPs have not been implemented on mined property. The impacts of the erosion east of CR 225 in Bradford County on land owned by the SRWMD needs to be addressed immediately and in the new NPDES permit.

The humate rich stormwater requires treatment with ferric solutions to remove the humate. Eliminating the waste product humate at its source is a waste reduction method. Reducing the amount of ferric solutions used should have a priority over doubling the permitted iron discharge levels that is [sic] proposed in the current permit application.

The apparent spill(s) of ferric solutions may require a review of the facility's BMPs and response procedures to spills of hazardous materials.

The water balance diagram included in the permit does not include watershed discharges. The water balance diagram shows an almost zero discharge operation. A revised water balance is needed.

DEP staff appear to have failed to review the abnormal events files for the Chemours facility. These abnormal events reports [sic] detail periods when water has passed over the spillway. Google Earth images also show apparent repairs to the spillway area. DEP staff appear to have failed to look at the path water takes after it passes over the spillway as erosion and sediments should have been clearly visible.

The failure to design for adequate stormwater storage at the West Levee could be corrected by fixing the erosion problem so rate of runoff is slowed or eliminated. This needs to be addressed in the permit. The inspection schedule for the West Levee is not acceptable.

61 The current stormwater systems transfer water from the SJRWMD and from 3 or more WBIDS to Alligator Creek. It is this transfer that may be contributing to flooding downstream of D001.

The end of pipe discharge from the two pumps at the West Levee would appear to be a point discharge that should be documented as to volume and water quality. It cannot be determined from the Google Earth images if the pipe discharges are contained conveyance system that would carry the mine contact water to the treatment facility or if the discharges can flow to other areas.

There is no indication that the settling ponds have had sludge removed. The holding capacity of the system may have been reduced to the point that it can no longer handle large rain events. An analysis of the current holding capacity of the setting ponds is needed.

\subsubsection{Discussion of Changes to Permit Limitations}

Changes to the FDEP Chemours' NPDES permit for Trail Ridge mining operations in Bradford County also were discussed in the Amendment, indicating that the "current wastewater permit for this facility FL0000051-012-IW3S expires on September 6, 2016". A relevant excerpt from pdf page 57 of that permit is included in Table 3. That statement does not consider controlled, pre-emptive discharges of heavy mineral mining wastewater by Chemours that may have occurred from the portion of the SRWMD's West Ridge Property located within the Trail Ridge mining boundaries prior to that inspection, but Paul Still, Supervisor of the Bradford Soil and Water Conservation District, identified Chemours' discharges in Bradford County as the source of both the flooding and sedimentation downstream of the D-001 discharge location in his complaints filed with Bradford County and FDEP.

Pre-emptive discharges of wastewater from large impoundments in Florida 
prior to anticipated periods of abnormal increases in precipitation are not uncommon in Florida. A notable example is the discharge of highly contaminated agricultural wastewater from Lake Okeechobee in south Florida prior to anticipated rapid increases in precipitation associated with hurricanes and tropical storms that could result in ruptures in the dyke completely surrounding that lake. Those types of pre-emptive discharges from the Chemours' impounded wastewater mine pits could exacerbate both offsite flooding and sedimentation downstream. Comments dated July 26, 2016, regarding the deficiencies of FDEP's proposed Chemours permit, identified additional fallacies of the October 27, 2015 inspection of the Chemours Trail Ridge Mine on pdf page 60 of that permit, which are included in Table 3. The NPDES Final Permit Renewal for Chemours in Bradford County also includes statements on pdf pages 60-61 dated July 26, 2016, as comments on the deficiencies of FDEP's Chemours permit (Table 3).

\subsubsection{No Supporting Documents}

The Amendment to the Fact Sheet for FDEP's Chemours NPDES permit in Bradford County also stated that there "are no supporting documents for the finding of facts in 6.b), c) and d) in the ADMINISTRATIVE ORDER ESTABLISHING COMPLIANCE SCHEDULE UNDER SECTIONS 403.088(2) and 403.067(7) F.S." The lack of supporting documents referenced in the Amendment to the Fact Sheet also included the statements from pdf pages 61-62 of Chemours' FDEP NPDES permit in Table 2.

\subsection{FDEP Monitoring Reports Required under Chemours' NPDES Permit in Bradford County}

\subsubsection{Discharge Monitoring Reports}

Pages 63-94 of the FDEP's Chemours NPDES permit in Bradford County include blank copies of forms and instructions for self-monitoring required by FDEP for that NPDES permit. The Discharge Monitoring Report (DMR) comprises Part A of the required monitoring reports and is included on pages 63-67 of FDEP's NPDES Final Permit Renewal for Chemours Trail Ridge mining in Bradford County. The instructions for the DMR-Part A of the self-monitoring reports are provided on page 77 of the permit. That form provides a box titled, "No Discharge from Site" that can be checked if the permittee claims that no discharge has occurred for that monitoring period. That form also includes a box titled, "Comment and Explanation of Any Violations" that can be checked if the permittee is self-reporting violations of permit conditions. These self-monitoring conditions in the FDEP permit make it extremely difficult, if not impossible for FDEP staff to document the accuracy of discharge-related violations that may contribute to or cause downstream flooding.

\subsection{2. $\mathrm{pH}$}

Page 64 of the DMR appears to allow a daily range in $\mathrm{pH}$ that is more than two orders of magnitude, from 6.0 as the daily minimum to 8.5 as the daily maxi- 
mum. Such a drastic range in $\mathrm{pH}$ alone, even in the absence of alterations of the natural hydroperiods and iron concentrations, could result in the premature decline and death of trees in contact with the discharged heavy mineral mining wastewater. For example, interstitial $\mathrm{pH}$ in the upper and lower soil horizons were 7.0 and 8.0, respectively, where bald-cypress (Taxodium distichum (L.) L.C. Rich.) were rooted in an unaltered stand of cypress with free-flowing hydrology along the St. Johns River, Florida in St. Johns County, adjacent to Clay County (Bacchus, 1990; Miller, Bacchus, \& Miller, 1993). Those $\mathrm{pH}$ values were consistent with other natural, unaltered stands of bald-cypress analyzed throughout Florida (S.T. Bacchus, unpublished data).

Conversely, the interstitial $\mathrm{pH}$ was 5.3 and 6.5 in the upper $15 \mathrm{~cm}$ (5.9 in) of soil surrounding the primary root mass of bald-cypress and lower soil horizon, respectively, in the eastern portion of the same bald-cypress stand where the hydrology had been altered by construction of a road that impounded the flow. The bald-cypress trees in the impounded portion of the bald-cypress stand were exhibiting typical signs of premature decline, exhibited by cypress subjected to chronic hydroperiod alteration with only half an order of magnitude change in natural pH conditions (Bacchus, 1990; Miller, Bacchus, \& Miller, 1993; S.T. Bacchus, unpublished data).

Additional cause for concern over the apparent 2.5 orders of magnitude in $\mathrm{pH}$ range allowed for Chemours' discharges of heavy mineral mining wastewater is that native plant and animal species with limited distribution (e.g., the federally endangered oval pigtoe mussel found only in a tributary to the SFR) may have considerably different $\mathrm{pH}$ requirements than commonly occurring species that are found in a broad range of habitats. One example is pond-cypress (Taxodium ascendens Brongn.), which has an interstitial $\mathrm{pH}$ of 4.5 in unaltered sites within its natural range that coincides with the extent of the Floridan aquifer system, compared to the $\mathrm{pH}$ range for bald-cypress. The US Fish and Wildlife Service (USFWS) designation for Critical Habitat for the federally endangered oval pigtoe mussel on November 15, 2007 (USFWS, 2007) states that "Various contaminants in point and non-point source discharges can degrade water and substrate quality and adversely affect mussel populations." That designation also states, "High temperatures or decreasing $\mathrm{pH}$ may increase the toxicity of metals to unionids (Havlik \& Marking, 1987, p. 14)." There was no indication that the impacts of such drastic changes in $\mathrm{pH}$, natural iron concentration, or any other component of the Chemours' discharges of heavy mineral mining wastewater on the oval pigtoe mussel were considered prior to the permitting of those Chemours discharges.

\subsection{Expenditures of Public Funds}

The approximately $\$ 2.8$ million funding from the USDA/NRDC, the SRWMD, and Bradford County in 2018 was not the first expenditure of public tax dollars on environmental damage to the SFR and tributaries not attributed to the dec- 
ades of Trail Ridge mining and discharges of heavy mineral mining wastewater by Chemours/DuPont. On September 14, 2012, Vanessa Fultz (SRWMD Office of Communications) issued a media release including the statements from pdf page 1 in Table 4 of Chemours' FDEP NPDES permit.

That September 2012 media release was preceded by a media release dated July 25, 2012, by the same SRWMD staff and office. The preceding media release stated that the SRWMD was "working in partnership with numerous agencies to mitigate flooding in Bradford County," including "Representatives from the County, the Bradford Soil and Water Conservation District, the Florida Department of Transportation (DOT), DuPont Mine, and Camp Blanding." The DuPont Mine referenced in that media release now is known as the Chemours Company TT LLC Trail Ridge mine. That flooding was attributed to Tropical Storms Beryl and Debby. That media release also stated that the SRWMD was partnering with FEMA to perform a flood study of Alligator Creek to set 100-year flood elevations. The July media release also stated that SRWMD would install automated water level gages on Lake Sampson and Alligator Creek to provide real-time flood information to the public and that flooding along Alligator Creek appeared to be caused by the inability of the creek to handle the amount of runoff produced by the storm rather than the water level in Lake Sampson, which is controlled by a floodgate. That media release also stated that

Table 4. Excerpts from the SRWMD media release dated September 14, 2012, describing the Alligator Creek Restoration project to restore and enhance the hydrology and aquatic habitat to remnant floodplain wetlands.

PDF Page
Numbers

The Suwannee River Water Management District (District) is working cooperatively with the Florida Fish and Wildlife Conservation Commission (FWC) and the City of Starke to restore a portion of Alligator Creek in Bradford County.

As part of the project, a sediment control structure will be constructed in the creek to capture and prevent sediment from entering Lake Rowell and to help restore the wetlands and floodplain by redirecting water into remnant creek channels on property owned by the City of Starke.

The Alligator Creek Restoration project will restore and enhance the hydrology and aquatic habitat of 31 acres of remnant floodplain wetlands and prevent 169 tons of sediment per year - the equivalent of 10 dump truck loads-from entering Lake Rowell," said Brian Kauffman, District senior professional engineer.

The City of Starke has agreed for the sediment control structure to be constructed on City property and to operate and maintain the structure after completion. The City has contributed $\$ 25,000$ toward the project, the FWC is providing $\$ 250,000$, and the District plans to contribute up to $\$ 325,000$, pending approval of the proposed Fiscal Year 2012-13 budget. The Federal Emergency Management Agency will conduct a flood study on Alligator Creek that will be used in construction plans.

The project supports the District's core mission goals to protect water quality, provide flood control, and protect natural systems. It is one of five major water quality improvement projects, in which the District has set aside \$2.9 million to implement during Fiscal Year 2012-13. 
"storm water discharged from DuPont had minimal effect on the overall flooding as this water was retained onsite and released after the peak of the storm event," without providing records of those discharges. That statement is inconsistent with subsequent observations by local residents of high water levels at bridged crossings for the SFR and tributaries in the vicinity of Chemours discharge locations for heavy mineral mining wastewater. Those observations by local residents included unexplained high water levels preceding the onset of storms and hurricanes, as well as during periods of no rainfall, suggesting Chemours discharges of heavy mineral mining wastewater as the source of those unexplained high water levels.

The NPDES Final Permit Renewal for Chemours in Bradford County recognizes the Chemours Trail Ridge mine as a "system that was designed and operated for the transport and movement of waters from one basin to the next basin". That suggests that the basin where the water is extracted may show evidence of dewatering, while the basin receiving the extracted water may experience abnormal flooding. Bernardes et al. (2014) supports the conclusion that groundwater depletion and transfer as surfacewater discharge to another basin (e.g., basin transport) is dewatering natural sinkhole lakes in Clay County, where the Trail Ridge mining was initiated decades ago by DuPont, as well as causing premature decline and death of trees in that county and surrounding counties. Those natural sinkhole lakes are considered endangered in Florida (Florida Natural Areas Inventory \& Florida Department of Natural Resources, 1990), which formed in relict sinkholes and are aligned along fractures.

\subsection{Increasing Flooding Associated with Santa Fe River in Proximity of 0'Leno State Park and Buzzards Roost Prairie}

Increased flooding has not been confined to the southern Alligator Creek, Lake Rowell, Lake Sampson, and the Sampson River in Bradford County, Florida following Tropical Storm Debby and Hurricane Irma, as indicated in the county's request for emergency funds from the USDA/NRCS and SRWMD. Increased severity and duration of flooding has been occurring in downstream reaches of the SFR in Alachua and Columbia Counties, in addition to locations of active USGS gage stations in the New River Near Lake Butler and SFR at Worthington Springs. The historical precipitation records do not support the conclusion that rainfall during Tropical Storm Debby and Hurricane Irma caused those increases in severity and duration of flooding. The extent and severity of flooding associated with Hurricane Irma in the lower SFR, in proximity to O'Leno State Park and Buzzards Roost Prairie have not been illustrated previously. We used available DEMs combined with modification of the NOAA method for mapping sea level rise inundation (NOAA, 2017) to incorporate hydrological connectivity for determining the lateral extent and relative depth of peak flooding in proximity to O'Leno State Park and Buzzards Roost Prairie, near Interstate 75 and Highway 41 (Figure 16). 


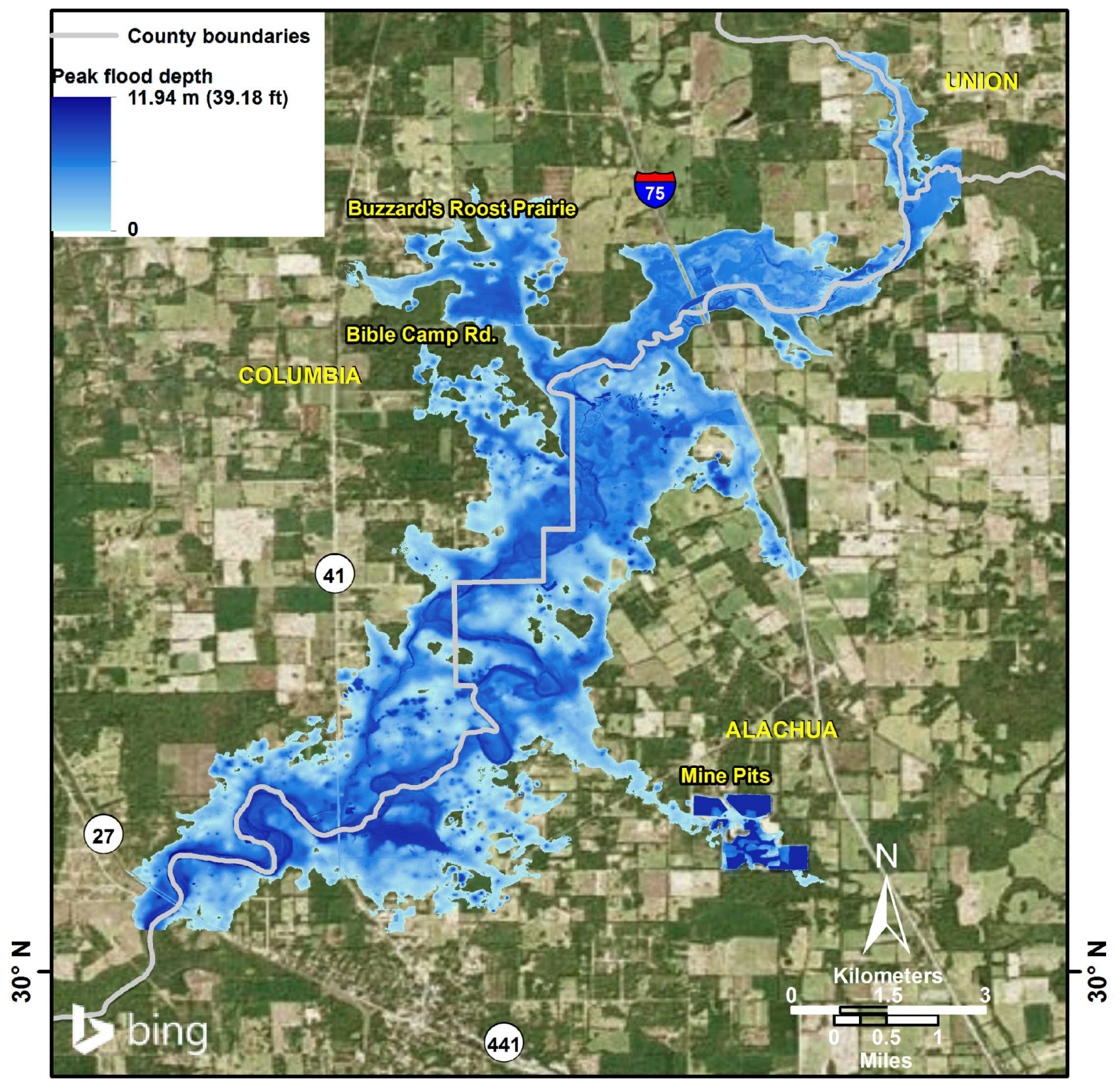

Figure 16. Lateral extent and relative depths of flooding associated with Hurricane Irma in the lower Santa Fe River vicinity of O’Leno State Park and Buzzards Roost Prairie, near Interstate 75 and Highway 41.

\section{Discussion}

\subsection{Fractures throughout the SFR Basin and Trail Ridge Mining Operations}

Figure 5, Figure 14, and Figure 15 display fractures previously mapped by Vernon (1951) and FDOT (1973) associated with USGS gage stations in the SFR Basin, the boundaries of the Chemours/DuPont Trail Ridge mining operation, and selected groundwater withdrawal locations and wastewater discharge locations. Those figures illustrate the highly fractured nature of the entire SFR Basin and Figure 5 illustrates the four-county area of the Chemours/DuPont Trail 
Ridge mining operation. Those figures also illustrate how hydrologic impacts from the mining and groundwater withdrawals for those mining operations can extend from the site of those mining operations, at the SFR headwaters, throughout the entire SFR Basin, associated counties, the SFR and all of the SFR tributaries, as well as the Osceola National Forest, via preferential flow through those fractures. Krause \& Randolph (1989) emphasized that fractures and other karst conduits that are pathways of preferential groundwater flow are not constrained by county, state, or other governmental boundaries.

Although our study did not include a detailed analysis of the fractures, the analyses of fractures and fracture intersections in two neighbor counties (Baker and Clay) conducted by Bernardes et al. (2014) provided relevant information regarding these fractures. Specifically, that study identified 220 fracture intersections in Baker County and 610 in Clay County for the fractures mapped by Vernon (1951) and FDOT (1973). The number of fracture intersections in Baker County was similar to the number of fracture intersections for Citrus and Levy Counties, 210 and 200, respectively, and fracture intersections are potential locations of interlinked cavities where changes in ground water may be magnified (Lines et al., 2012).

Another important consideration described in Bernardes et al. (2014) was that microfracture abundance was related directly to macrofracture abundance (Marrett, Ortega, \& Kelsey, 1999; Ortega \& Marrett, 2000) in many cases. Microfractures were not mapped by FDOT (1973) or by Vernon (1951). Microfractures also were not addressed by Faulkner (1973), which described additional related work by Vernon and personal communications with Vernon, as well as fractures described in Vernon's initial publication addressing fractures in the north Florida area of the Floridan aquifer system (Vernon, 1951).

\subsection{Comparison of Historical Precipitation, Stream Gage Data and Accounts by Local Residents}

\subsubsection{Historical Precipitation}

The horizontal line in Figure 2 illustrates total monthly precipitation peaks for previous storm events in the SFR Basin that were comparable to or exceeded the total monthly precipitation peak in September 2017, during Hurricane Irma. Those previous peaks comparable to or exceeding the monthly precipitation associated with Hurricane Irma were not addressed by Bradford County, federal agencies, or the SRWMD as resulting in comparable flooding in areas of record flooding attributed to Hurricane Irma (e.g., Bradford County, Worthington Springs, Buzzards Roost Prairie). Figure 2 also illustrates that total monthly precipitation associated with Hurricane Irma in 2017 was approximately half that of the total monthly precipitation associated with Debby in 2012, and with Frances + Ivan in 2004, but without the record stream discharges and gage heights in the SFR Basin during Hurricane Irma.

Figure 2 includes the storms and hurricanes identified by agencies and Bradford County as causing flood events, as well as those that influenced the SFR Ba- 
sin that were considered in our study. The chronological order of those storms, followed by the date/year of the storm and the total monthly precipitation are: Hurricane Dora (9/64 - $304.3 \mathrm{~mm}$ ); "No Name Storm" (3/93 - $93.2 \mathrm{~mm}$ ); Hurricanes Frances + Ivan (9/04 - 474.8 mm); Tropical Storm Beryl (5/12 - 211.3 $\mathrm{mm})$; Tropical Storm Debby (6/12 - 520.1 mm); Hurricane Hermine (9/16 $185.8 \mathrm{~mm})$; Hurricane Irma $(9 / 17-309.4 \mathrm{~mm})$. Those total monthly precipitation values do not increase chronologically for those storms. For example the total monthly precipitation for the two most recent storms, Hurricane Hermine in 2016 and Hurricane Irma in 2017, both are less than the monthly precipitation for Hurricanes Frances + Ivan in 2004. That is significant because long-time residents of the lower SFR near O'Leno State Park, including Tyler Harris in Buzzards Roost Prairie, Columbia County and Jane Blais in Alachua County, both have recorded continually increasing flood levels structures and trees on their property during those recent storms. Both of those residents own property and live in the area between Interstate 75 and Highway 41, where flooding from Hurricane Irma was extensive and long-lasting (personal communication, T. Harris, 3/18). Buzzards Roost Prairie residents reported that the depths and duration of flooding have increased on their property with each storm/hurricane since the "No Name Storm". Specifically, one of the higher elevation properties in Buzzards Roost Prairie (purchased after the "No Name Storm" in 1993) had floodwaters approximately $2 \mathrm{~m}$ (6 ft) deep for Frances and Ivan in 2004, $3.4 \mathrm{~m}$ (11 ft) deep for Beryl and Debby in 2012, and 4.6 - $5.2 \mathrm{~m}$ (15 - $17 \mathrm{ft}$ ) deep for Irma in 2017 (personal communication, T. Harris, 3/18). That report of increasing depth and duration of flooding on personal properties of long-time residents for recent storms/hurricanes, was corroborated by an Alachua County resident who has lived adjacent to the SFR near Highway 41 since 1998 (personal communication, J. Blais, 3/18).

The total monthly precipitation also is not consistent with similar reports provided for the Worthington Springs area of increasing magnitude and extent of flooding since Hurricane Dora, particularly during the past five years, based on observations of long-time Worthington Springs resident Richard Cason (personal communication, R. Cason 1/19). Those reports of extreme flooding, increasing in magnitude and extent, associated with Hurricane Irma also are consistent with reports from residents living in Bradford County, in the vicinity of Alligator Creek, Lake Rowell, Lake Sampson, the Sampson River, and Little Santa Fe Lake. Those accounts of extreme flooding, increasing in magnitude and extent, in Bradford County were not confined to Paul Still, but included Steve Lodle (personal communication, S. Lodle, 4/18) and Tom Germano (personal communication, T. Germano, 2/18, 3/18). Alligator Creek, Lake Rowell, Lake Sampson, and the Sampson River all are downstream of the permitted Chemours' discharges of heavy mineral mining wastewater from D-001. Little Santa Fe Lake is downstream of the permitted Chemours' discharges of heavy mineral mining wastewater from D-002. Those reports by property owners and residents 
of Bradford County of extreme flooding, increasing in magnitude and extent, associated with Hurricane Irma also are inconsistent with total monthly precipitation shown for Hurricane Irma in Figure 2.

The total monthly precipitation reported in the area of the SFR headwaters (Figure 3(b)), for the storms and hurricanes considered in our study, and the total monthly precipitation reported for the entire SFR Basin (Figure 3(a)) for those same months and years were not identical. The small differences in Figure 3(b) would not influence the flooding in the area funded by the USDA/NRCS DSR emergency project grant for flood abatement, tree removal, and sediment removal, with non-federal funding from the SRWMD and Bradford County. That is because the rainfall reported for the SFR headwaters location (Figure 3(b)) discharges directly to the upper SFR, south of the USDA/NRCS project area in Bradford County, flowing west to the lower SFR. The area covered by the USDA/NRCS DSR emergency project grant for flood abatement, tree removal, and sediment removal, begins at the headwaters of Alligator Creek at the north end of the Chemours/DuPont mining operations in Bradford County (Figure 17), shown as an open-water pit in Figure 12(b) and Figure 17. That area receives the Chemours/DuPont heavy mineral mining wastewater discharges from D-001 authorized by the FDEP NPDES permit, flowing north, the west through Starke (Figure 12(b)), then southwest into Lake Rowell (Figure 12(a)), then south into the Sampson River, before finally flowing south in the Sampson River, then into the SFR west (downstream) of the headwaters gage for the USGS SFR Near Graham gage station.

Figure 4(a) and Figure 4(b), suggest that 30-year averages of total monthly precipitation calculated for three time periods spanning 1928-2017 have remained

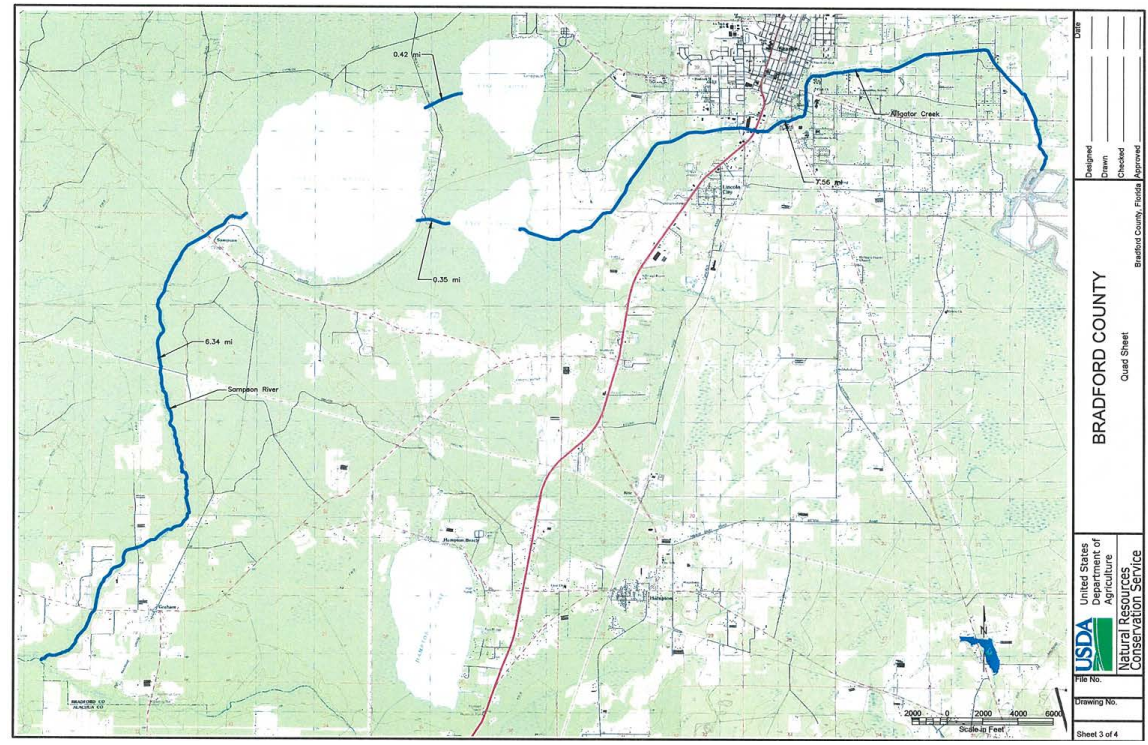

Figure 17. USDA/NRCS Bradford County flood abatement map beginning at the headwaters of the Alligator Creek mined by Chemours/DuPont, and continuing through Lakes Rowell and Sampson, and the Sampson River, to the confluence with the Santa Fe River. 
relatively constant for the entire SFR Basin, as well as in the SFR headwaters, despite the increase in flooding during recent tropical storms and hurricanes downstream of the Chemours' discharges of heavy mineral mining wastewater. The increases in precipitation from June through September in all three 30-year periods for the entire SFR Basin and the SFR headwaters, respectively, occur during the annual hurricane season. The official hurricane season for Florida and the entire Atlantic-Caribbean Sea-Gulf of Mexico area begins June 1st and ends November 30th (NOAA, 2019).

The area covered by the USDA/NRCS DSR emergency project grant for flood abatement, tree removal, and sediment removal, includes the entire area from the upper reach of Alligator Creek through the Sampson River (Figure 17). Those tributaries of the SFR in the flood abatement project area are illustrated by the purple dots in the vicinity of Starke and orange dots southwest of Starke that represent inactive gage stations on the Alligator Creek and Sampson River in Figure 5.

Additionally, the Chemours/DuPont Trail Ridge mining operations have resulted in permanent removal of the headwater wetlands of Alligator Creek in Bradford County (Figure 13(b)). Those headwater wetlands would have retained precipitation from Hurricane Irma and future storms and hurricanes, as well as from previous storms and hurricanes dating back to when Chemours/ DuPont initiated mining in those headwater wetlands. In addition to permanently eliminating the amelioration of precipitation from hurricanes and other storms, the permanent loss of those headwater wetlands also eliminated the natural recharge of the regional Floridan aquifer system provided by those headwater wetlands.

\subsubsection{Hurricane Dora}

Richard Cason provided the same reports of the magnitude of flooding increasing in the Worthington Springs area with each hurricane and tropical storm since Hurricane Dora in September 1964 to Hurricane Irma in 2017, particularly within the past five years. He has been a resident of the Worthington Springs area since 1957 (personal communication, R. Cason, 1/19).

Hurricane Dora was the first hurricane to significantly impact northeast Florida in the 1900s. As Hurricane Dora approached the east coast of north Florida, its movement slowed. Tides peaked at approximately $4 \mathrm{~m}(12 \mathrm{ft})$ at Anastasia Island. The eye of the storm made landfall at St. Augustine, Florida a little after midnight on September 10, 1964. The heaviest rain fell during September 11th and 12th, 1964 and the storm doubled back to the east (National Hurricane Center, 1964; NOAA, 1964). Tracking of Hurricane Dora's center from September 9 - 12, 1964 and maximum rainfall of $602.7 \mathrm{~mm}$ (23.7 in) recorded in Mayo, Florida during this hurricane is provided by the National Hurricane Center (1964). Mayo, Florida is located approximately $72 \mathrm{~km}(45 \mathrm{mi})$, straight-line distance, west of Worthington Springs, Florida. 


\subsubsection{Video Documentation of SFR Flooding Associated with Hurricane} Irma on September 11, 2017

Chastain-Seay Park, located on the SFR in Worthington Springs, was closed after the severe flooding during Hurricane Irma and has not been reopened since that flooding. James Cason, Mayor of Worthington Springs, and the father of Richard Cason established Chastain-Seay Park in approximately 2001. Prior to flooding associated with Hurricane Irma, the park provided recreational opportunities that included boat launching, fishing, and pavilions for day picnicking. Richard Cason's grandmother, Ruth Roberts Cason, routinely swam in Worthington Springs in the early 1900s (personal communication, R. Cason 1/19). The town of Worthington Springs was named after that spring, which was a large tourist attraction during the early 1990s. Historic photographs of Worthington Springs during its prime days as a tourist attraction and during the period of time encompassing our study, and consistent with observations made during our study, are provided at the following link:

http://www.desolationflorida.com/2016/03/worthington-springs.html.

The Springs of Florida (Rosenau, Faulkner, Hendry \& Hull, 1977) included the following information regarding the demise of that spring:

On April 24, 1972, highly colored water from the river was backed up over the spring and into the swimming pool: no flow was evident. When the spring is flowing, the spring water may have appreciable color... Utilization-None.

The "highly colored water from the river" referenced in that publication is from natural levels of tannic acid characteristic of Florida's "Blackwater Stream" ecosystems (Florida Natural Areas Inventory \& Florida Department of Natural Resources, 1990) The reference to "appreciable color" when the spring is flowing is indicative of the limited flow of ground water from the Floridan aquifer system from that spring, because that groundwater flow characteristically is crystal clear and without any significant tannins that would impart the "appreciable color" of surface water from the streams. The demise of the name-sake spring in the town of Worthington Springs, Florida is similar to the demise of Kissengen Springs from phosphate mining in the Peace River Basin (Lewelling et al., 1998) and the demise of the name-sake spring in the town of White Springs, Florida from phosphate mining of tributary wetlands to the Suwannee River.

An audio/video recording of the flooding associated with Hurricane Irma on September 11, 2017 at the State Road 121 bridge over the SFR in Worthington Springs was created by a Union County resident and is available online (https://youtu.be/ag-ZwZxXt9Y, personal communication, M. Burton 2/19). In that video, USGS staff monitoring the flooding confirm that discharge at that location was the "highest they ever recorded," at "almost 25,000 cubic feet per second" $\left(\mathrm{ft}^{3} \mathrm{sec}^{-1}\right)$. That discharge is consistent with the record discharge spike shown in Figure $7(\mathrm{a})$ and was approximately $283.2 \mathrm{~m}^{3} \mathrm{sec}^{-1}\left(10,000 \mathrm{ft}^{3} \mathrm{sec}^{-1}\right)$ greater than previous peak discharges that occurred in October 5, 1992 and June 
28, 2012 shown in Figure 7(a). Monthly precipitation for the SFR basin and those two previous peak discharges were $155.1 \mathrm{~mm}(6.1 \mathrm{in})$ and $520.1 \mathrm{~mm}(20.5$ in), respectively. A similar record gage height of approximately $9 \mathrm{~m}(30 \mathrm{ft})$ at the Worthington Springs gage station for September 2017 is shown in Figure 7(b). Previous peak gage heights at that location were approximately $6.4 \mathrm{~m}(20.9 \mathrm{ft})$ in

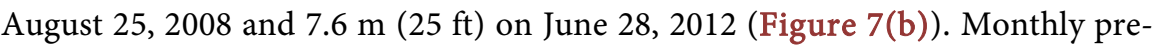
cipitation for those two previous peak gage heights was $312.1 \mathrm{~mm}$ (12.3 in) and $520.1 \mathrm{~mm}$ (20.5 in), respectively.

That video of SFR flooding associated with Hurricane Irma on September 11, 2017, at the USGS Worthington Springs gage station, shows the magnitude of the flooding downstream (west) of the State Road 121 Bridge, from the south bank of the SFR at the beginning of the video to the north bank of the SFR at the end of the video. Approximately the left $75 \%$ of the last frames of that video show the flooding of the area of the entrance road to the Chastain-Seay Park, which was submerged by the flooding (personal communication, R. Cason, 1/19). A brief, second audio/video recording taken by the same Union County resident on the same day at the same SFR downstream location from State Road 121 shows the flooded area of Chastain-Seay Park facilities adjacent to the north bank of the SFR (personal communication, M. Burton, 2/19). That audio/video also is available online (https://youtu.be/qk2IW0EZEjo, personal communication, M. Burton, 2/19). A third audio/video recording taken by the same Union County resident on the same day shows flooding of the SFR upstream (east) of State Road 121 and that bridge over the SFR and also is available online (https://youtu.be/UOub4s28jpA, personal communication, M. Burton, 2/19). That video of the downstream portion of the SFR includes evidence of premature decline in trees associated with the SFR that is consistent with long-term anthropogenic hydroperiod alterations, such as mining, described in Bacchus (2006), Bacchus et al. (2011), and Bernardes et al. (2014).

\subsubsection{Video Documentation of New River Flooding Associated with Hurricane Irma on September 11, 2017}

The location of SFR flooding associated with Hurricane Irma on September 11, 2017, shown in the video taken at USGS SFR at Worthington Springs gage station, is less than a kilometer (mile) downstream from the confluence of the New River tributary flowing into the SFR. The USGS gage at that New River location is not active, as indicated by the pink circle symbol at the confluence of the New River with SFR in Figure 5. An additional video of flooding associated with Hurricane Irma on September 11, 2017, was taken by the same Union County resident in the vicinity of that location, from County Road 18 over the New River approximately $0.8 \mathrm{~km}(0.5 \mathrm{mi})$ upstream of the confluence with the SFR (personal communication, M. Burton, 2/19). A copy of that video also is available online (https://youtu.be/41xRD_m3lac, personal communication, M. Burton, 2/19). In the absence of USGS gage data at that location for the New River, that video provides information regarding the magnitude of flooding at that location 
for the New River. That video is facing southeast on County Road 18, toward Brooker, and shows the entire County Road 18 bridge under water, with water submerging the road extending approximately $0.23 \mathrm{~km}(750 \mathrm{ft})$ from the center of the bridge, northwest to the SW 125th Loop entrance to the Flying Tiger Airport on the left side of the video (personal communication, M. Burton 2/18; 2/19).

A second video showing flooding of the New River associated with Hurricane Irma on September 11, 2017 was taken north of the State Road 231 bridge over the New River, near Scout Hole in Union County by the same resident. Scout Hole is a local name for private property less than $0.3 \mathrm{~km}(1000 \mathrm{ft})$ west of the New River channel, upstream of State Road 231. The mobile home community at Scout Hole flooded during this event (personal communication, M. Burton, $2 / 18 ; 2 / 19$ ). That video also is available online (https://youtu.be/dYPjk6xkfcM, personal communication, M. Burton, 2/19). This video taken from State Road 231 also shows trees with evidence of premature decline in trees associated with the New River that is consistent with long-term anthropogenic hydroperiod alterations, such as mining, described in Bacchus (2006), Bacchus et al. (2011), and Bernardes et al. (2014).

\subsubsection{Historical Stream Gage Data}

The only active USGS gage station on the New River, upstream of the confluence of the New River with the SFR, is the USGS New River Near Lake Butler. That gage station is marked by the pink diamond symbol in Figure 5 . That active gage station is located approximately one-third the distance northeast from the SFR at Worthington Springs gage station and the clusters of discharges of Chemours' heavy mineral mining wastewater permitted by FDEP in Baker County (yellow circles in Figure 5). The discharge and gage height data for SFR New River Near Lake Butler are included in Figure 8(a) and Figure 8(b), respectively. The record discharge and gage height for that New River gage station associated with Hurricane Irma were $413.4 \mathrm{~m}^{3} \mathrm{sec}^{-1}\left(14,600 \mathrm{ft}^{3} \mathrm{sec}^{-1}\right)$ and $4.8 \mathrm{~m}(15.6$ $\mathrm{ft})$, respectively. That record discharge was approximately $113.7 \mathrm{~m}^{3} \mathrm{sec}^{-1}(4000$ $\mathrm{ft}^{3} \sec ^{-1}$ ) greater than the previous two peak discharges on October 4, 1992 and June 27, 2012, associated with an event not evaluated in our study and Tropical Storm Debby, respectively. Record gage height at that location for September

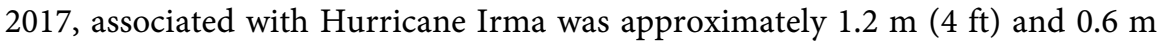
(2 ft) greater than the previous two gage heights on August 23, 2008 and June 27, 2012, associated with a storm event not evaluated in our study and Tropical Storm Debby, respectively. The peak discharge and gage height at that New River gage station associated with Hurricane Irma are not consistent with the precipitation records for the SFR Basin associated with that hurricane. For instance, total monthly precipitation for the SFR Basin in September 2017 (Hurricane Irma) was $309.4 \mathrm{~mm}$ (12.2 in), while total monthly precipitation in June 2012 (Tropical Storm Debby) was $520.1 \mathrm{~mm}$ (20.5 in). That suggests that the magnitude of discharges of Chemours' heavy mineral mining wastewater were respon- 
sible for those record discharge and gage height at that New River gage station and flooding downstream, including, but not limited to, Worthington Springs, O'Leno State Park, and Buzzards Roost Prairie associated with Hurricane Irma.

The graph of record stream discharge of $671.1 \mathrm{~m}^{3} \mathrm{sec}^{-1}\left(23,700 \mathrm{ft}^{3} \mathrm{sec}^{-1}\right)$ at the USGS SFR at Worthington Springs gage station in September, 2017, during the approximate time of Hurricane Irma, was approximately $240.7 \mathrm{~m}^{3} \mathrm{sec}^{-1}(8500$ $\mathrm{ft}^{3} \mathrm{sec}^{-1}$ ) greater than the previous two record peak discharges. Those previous two peak discharges at Worthington Springs occurred in October 1992 and June 2012, associated with an event not evaluated in our study and Tropical Storm Debby, respectively (Figure 7(a)). The graph of record stream gage height of approximately $9 \mathrm{~m}(29.5 \mathrm{ft})$ at the USGS SFR at Worthington Springs gage station in September 2017, associated with Hurricane Irma, was approximately 2.6 $\mathrm{m}(8.5 \mathrm{ft})$ and $1.4 \mathrm{~m}(4.5 \mathrm{ft})$ greater than the previous two peak gage heights at that gage station in August 2008 and June 2012, associated with an event not evaluated in our study and Tropical Storm Debby, respectively (Figure 7(b)).

The only active USGS gage station on the SFR upstream of the USGS SFR at Worthington Springs gage station is the USGS SFR Near Graham gage station (Figure 6(a) and Figure 6(b)). That gage station is marked by a white diamond symbol on Figure 5 and is located east approximately halfway between the SFR gage station at Worthington Springs and the two discharge locations (i.e., D-001 and D-002) for Chemours' heavy mineral mining wastewater permitted by FDEP in Bradford County, identified as yellow circles in Figure 5. The record discharge and gage height for that gage station SFR Near Graham, associated with Hurricane Irma were $134.5 \mathrm{~m}^{3} \mathrm{sec}^{-1}\left(4750 \mathrm{ft}^{3} \mathrm{sec}^{-1}\right)$ and $5.2 \mathrm{~m}(17.1 \mathrm{ft})$, respectively (Figure 6(a) and Figure 6(b)). That record discharge was more than 85 $\mathrm{m}^{3} \sec ^{-1}\left(3000 \mathrm{ft}^{3} \mathrm{sec}^{-1}\right)$ greater than the previous two peak discharges in February, 1998 and June 2012, associated with an event not evaluated in our study, and Tropical Storm Debby, respectively. That record gage height was approximately $1 \mathrm{~m}$ (3.3 ft) greater than the previous peak gage height in June 2012, associated with Tropical Storm Debby. That record gage height also was more than $1.4 \mathrm{~m}(4.5 \mathrm{ft}$ ) greater than a previous peak gage height in January, 2010 (event not evaluated in our study) and more than $2.5 \mathrm{~m}(8.2 \mathrm{ft})$ greater than a peak gage height in September 2016 (Hurricane Hermine). The peak discharge and gage height associated with Hurricane Irma at that SFR gage station also are not consistent with the considerably lower precipitation records for the SFR headwaters near Graham during September 2017 for Hurricane Irma. That suggests discharges of Chemours' heavy mineral mining wastewater from D-001 to Alligator Creek, Lake Rowell, Lake Sampson, and the Sampson River, prior to discharging into the SFR, were a factor in the flooding in Bradford County. That also suggests that at least a portion of discharges of Chemours' heavy mineral mining wastewater were diverted to the D-002 location and possibly north to Water Oak Creek. Those discharges could contribute to the flooding associated with Hurricane Irma at the SFR headwaters and downstream SFR locations, in addition to 
Worthington Springs, upstream of Water Oak Creek, respectively. Downstream locations for the SFR include, but are not limited to, Little Santa Fe Lake, O'Leno State Park, and Buzzards Roost Prairie.

Two active USGS gage stations on the SFR are located downstream of the USGS SFR at Worthington Springs gage station in our study area. Those gage stations are SFR at O'Leno State Park and SFR at River Rise Near High Springs. The locations of those two gage stations are marked by the white diamond symbols in Figure 5. The peak discharges associated with Hurricane Irma at those two gage stations were $750.4 \mathrm{~m}^{3} \mathrm{sec}^{-1}\left(26,500 \mathrm{ft}^{3} \mathrm{sec}^{-1}\right)$ and $529.5 \mathrm{~m}^{3} \mathrm{sec}^{-1}(18,700$ $\mathrm{ft}^{3} \mathrm{sec}^{-1}$ ), shown respectively in Figure 9(a) and Figure 10(a). Those peaks exceeded the previous peak at those two gage stations by approximately 342.6 $\mathrm{m}^{3} \sec ^{-1}\left(12,100 \mathrm{ft}^{3} \mathrm{sec}^{-1}\right)$ in June 2012 for the SFR at O'Leno State Park gage station, associated with Tropical Storm Debby and $719 \mathrm{~m}^{3} \mathrm{sec}^{-1}\left(25,390 \mathrm{ft}^{3} \mathrm{sec}^{-1}\right)$ at SFR at River Rise Near High Springs, associated with Hurricane Hermine. The peak gage heights associated with Hurricane Irma were $17.6 \mathrm{~m}(57.7 \mathrm{ft})$ and 6.4 m (21.1 ft) for the SFR at O'Leno State Park and SFR at River Rise Near High Springs gages, as shown respectively in Figure 9(b) and Figure 10(b). The peak gage height for Hurricane Irma at the O'Leno gage station was $1 \mathrm{~m}(3.3 \mathrm{ft})$ greater than the previous peak in June 2012.

Comparison of the historical precipitation data to the historical stream gage data displayed in Figure 6 through Figure 10 does not support the conclusion that precipitation from Hurricane Irma alone resulted in the extensive flood levels and durations associated with Hurricane Irma in Bradford County and in the lower SFR, including at Buzzard's Roost Prairie. That comparison also did not support the record stream discharges at the SFR at Worthington Springs gage station.

Specifically, those recorded stream discharges and gage heights for the SFR Near Graham suggest that Chemours discharges of heavy mineral mining wastewater from D-001 may be flowing into and through the Santa Fe Swamp to this USGS gage station and/or that the long-term groundwater withdrawals for the Chemours/DuPont Trail Ridge mining operations have resulted in such severe alteration of the natural hydroperiod of the Santa Fe Swamp that those SFR headwaters no longer are capable of functioning as headwater wetlands, retaining and storing water. The fact that the entire Santa Fe Swamp cypress stand ignited and burned, killing the fire-adapted pond-cypress, supports the conclusion that severe alteration of the natural hydroperiod, including dewatering of the organic cypress soils, has occurred. Catastrophic fires that destroy pond-cypress wetlands are characteristic of those types of anthropogenic hydroperiod alterations (Bacchus, 2006, 2007).

\subsection{Inactive USGS Monitoring Locations and Historical USGS Photographs of the Santa Fe River and New River}

\subsubsection{Inactive USGS Monitoring Locations}

The map in Figure 5 shows additional USGS monitoring locations that currently 
are inactive. The cluster of inactive Alligator Creek USGS monitoring locations and two inactive Sampson River USGS monitoring locations are located west of the western discharge location for heavy mineral mining wastewater permitted by FDEP to convey that industrial wastewater from the southern boundaries of the Chemours Trail Ridge mining operations in Bradford County. Those discharges of heavy mineral mining wastewater flow through Lake Rowell, Lake Sampson, and the Sampson River, to the SFR. Long-term data from those monitoring locations could have provided valuable records of both stream discharges and discharges of heavy mineral mining wastewater.

The two inactive Alligator Creek monitoring stations located southwest of the northern boundaries of the Chemours Trail Ridge mining operations are in a separate Alligator Creek that was not permitted by FDEP as receiving waters for Chemours' heavy mineral mining wastewater from the Trail Ridge mining operations. The northern Alligator Creek in Bradford County flows into the New River, north of the confluence of Water Oak Creek with the New River. Longterm stream discharge and gage height data from those inactive monitoring locations also could have been valuable as background data to compare with the southern Alligator Creek in Bradford County, where discharges of heavy mineral mining wastewater from Chemours Trail Ridge mining operations are permitted by FDEP. Historical stream discharge and gage height data from inactive USGS New River monitoring sites at or below the confluence of the northern Alligator Creek with the New River, and at the inactive USGS monitoring sites, both upstream and downstream of the Lake Butler Wildlife Management Area, northeast of Raiford Prison also could have provided valuable background and comparison data.

Water quality data from the inactive USGS monitoring locations in Olustee Creek could have served as control-site data for comparison with water quality data from the southern Alligator Creek in Bradford County, receiving Chemours' discharges of heavy mineral mining wastewater. Ocean Pond, surrounded by the Osceola National Forest and Wildlife Management Area, is the headwaters of Olustee Creek, which flows south into the SFR. Additionally, stream discharge and gage height data from the inactive USGS monitoring locations in Olustee Creek also could have provided valuable comparisons to data from other SFR tributaries closer to the Chemours Trail Ridge mining operations.

New phosphate mining has been proposed in Bradford and Union Counties and has been under consideration by FDEP, as well as by those counties for several years. Although the additional historical stream discharge, gage height, and water quality data from those inactive USGS monitoring stations would have been valuable for our analysis, data from those inactive USGS monitoring stations are essential for a meaningful consideration of additional phosphate mining, increasing the magnitude of mining in that area beyond that of the Trail Ridge mining. 


\subsubsection{Historical USGS Photographs of the Santa Fe River and New River}

The presence of numerous dead and fallen trees associated with the SFR and New River gage stations in historical USGS photographs (Figure 11) approximately ten years before Hurricane Irma crossed the SFR Basin in 2017, is relevant because funding from the USDA/NRCS and SRWMD for Bradford County was based in part on presumptions that Hurricane Irma had resulted in the death and downfall of trees in SFR tributaries in that vicinity (i.e., Alligator Creek and the Sampson River). That presumption also included the presumption that those fallen trees impeded flow of flood waters during Hurricane Irma, resulting in and prolonging flooding in Bradford County, as justification for the emergency grant from USDA/NRCS to remove those trees and dredge sediment from those stream channels.

The evaluation conducted in the vicinity of Trail Ridge mining and described in Bernardes et al. (2014) provided additional evidence that native trees and other vegetation in the vicinity of the Trail Ridge mining were exhibiting signs of altered natural hydroperiods typical of large-scale, long-term mining and groundwater withdrawals. Those signs included premature decline and death of native trees. A more detailed evaluation of the condition of native trees and other vegetation in the vicinity of the Trail Ridge mining operations could provide more extensive information.

\section{Conclusion}

Comparisons of the historical precipitation data and historical USGS stream discharge and gage height data for the SFR Basin and headwaters do not support the conclusion that total precipitation (rainfall) during Hurricane Irma alone caused those increases in severity and duration of flooding in the SFR Basin. The fact that flooding downstream of the Chemours/DuPont discharge locations did not occur or was less severe during previous tropical storms and hurricanes with greater associated total precipitation than during Hurricane Irma supports the conclusion that severe flooding in Bradford County and downstream associated with Hurricane Irma was not the result only of total precipitation produced by that hurricane. Additionally, historical USGS photographs show tree death and downfall in both the SFR and New River that predate both Tropical Storm Debby (in 2012) and Hurricane Irma (in 2017). Those historical photographs, combined with the additional documentation of premature decline and death of trees in that vicinity (Bernardes et al., 2014) prior to Hurricane Irma, and extensive documentation in published literature of premature decline and death of trees, including tree fall, solely from groundwater alterations and in the absence of tropical storms and hurricanes support the conclusion that groundwater alterations rather than total rainfall and winds from Hurricane Irma were responsible for tree deaths and downfall in upstream tributaries of the SFR in Bradford County. Discharges authorized by FDEP's NPDES permit of " 40 million gallons a day" and "55.3 MGD during tropical storm Debbie" [sic] of heavy mineral 
mining wastewater from the Chemours/DuPont Trail Ridge mining operations to tributaries of the SFR in Bradford and possibly Baker Counties suggest that these discharges are contributing to the increasing severity and duration of flooding in the SFR Basin.

The fracture networks throughout the Chemours/DuPont Trail Ridge mining area, initially in Clay and Bradford Counties and currently in Baker and Duval Counties, and in proximity to the CUP wells for those mining operations, also can contribute to the irreversible alteration of natural hydroperiods, in addition to widespread induced recharge and dewatering of the surficial aquifer, and surface waters, including streams, natural lakes, and wetlands associated with those fractures. Those adverse impacts can occur for many kilometers (miles) from that mining area. The increasing magnitude of the severity and duration of flooding in the SFR Basin, combined with the irreversible adverse impacts to vegetation, surface waters, and the regional Floridan aquifer system, in addition to the potential adverse impacts to the federally endangered oval pigtoe mussel and designated critical habitat, should be sufficient for the US Army Corps of Engineers (USACOE), the USEPA, and the USFWS to initiate a comprehensive Area-wide Environmental Impact Statement, considering the regional cumulative impacts of this mining, combined with the proposed new phosphate mining in Bradford and Union Counties.

\section{Acknowledgements}

Our manuscript benefitted from extensive peer-review comments provided by the editor, anonymous review, and Todd Kincaid. Our evaluation would not have been possible without the long-term precipitation data provided by the PRISM Climate Group, and the water-level data, discharge data, and historical photographs for the SFR and tributaries from the USGS. We also thank the managing editor for prompt assistance throughout the peer-review and prepublication process.

\section{Conflicts of Interest}

The authors declare no conflicts of interest regarding the publication of this paper.

\section{References}

Bacchus, S. T. (1990). Ecological Factors Associated with Pond-Cypress (Taxodium ascendens) and Bald-Cypress (T. distichum). Florida Scientist, 53, 20.

Bacchus, S. T. (1997a). Premature Decline and Death of Trees Associated with a Man-Made Lake and Groundwater Withdrawals in Albany, Georgia. In Georgia Water Resources Conference (pp. 280-286). Athens: The University of Georgia.

Bacchus, S. T. (1997b). Subsidence Features, and Premature Decline and Death of Trees in Cumberland National Seashore Wilderness Area, Georgia. In Reconnaissance Report to the National Park Service (p. 29). Washington, DC.

Bacchus, S. T. (1999). Cumberland Island National Seashore: Linking Offshore Impacts to 
Mainland Withdrawals from a Regional Karst Aquifer. In Proceedings of the 1999 Georgia Water Resources Conference (pp. 463-472). Athens: The University of Georgia.

Bacchus, S. T. (2000). Uncalculated Impacts of Unsustainable Aquifer Yield Including Evidence of Subsurface Interbasin Flow. Journal of the American Water Resources Association, 36, 457-481. https://doi.org/10.1111/j.1752-1688.2000.tb04279.x

Bacchus, S. T. (2006). Nonmechanical Dewatering of the Regional Floridan Aquifer System. In R. S. Harmon, \& C. M. Wicks (Eds.), Perspectives on Karst Geomorphology, Hydrology, and Geochemistry: A Tribute Volume to Derek C. Ford and William B. White (Vol. 404, pp. 219-234). Boulder, CO: Geological Society of America. https://doi.org/10.1130/2006.2404(18)

Bacchus, S. T. (2007). More Inconvenient Truths: Wildfires and Wetlands, SWANCC and Rapanos. National Wetlands Newsletter, 29, 15-21.

Bacchus, S. T., Archibald, D. D., Britton, K. O., \& Haines, B. L. (2005). Near Infrared Model Development for Pond-Cypress Subjected to Chronic Water Stress and Botryosphaeria rhodina. Acta Phytopathologica et Entomologica Hungarica, 40, 251-265. https://doi.org/10.1556/APhyt.40.2005.3-4.6

Bacchus, S. T., Archibald, D. D., Brook, G. A., Britton, K. O., Haines, B. L., Rathbun, S. L., \& Madden, M. (2003). Nearinfrared Spectroscopy of a Hydroecological Indicator: New Tool for Determining Sustainable Yield for Floridan Aquifer System. Hydrological Processes, 17, 1785-1809. https://doi.org/10.1002/hyp.1213

Bacchus, S. T., \& Barile, P. J. (2005). Discriminating Sources and Flowpaths of Anthropogenic Nitrogen Discharges to Florida Springs, Streams and Lakes. Environmental and Engineering Geoscience, 11, 347-369. https://doi.org/10.2113/11.4.347

Bacchus, S. T., Bernardes, S., Jordan, T., \& Madden, M. (2014). Benthic Macroalgal Blooms as Indicators of Nutrient Loading from Aquifer-Injected Sewage Effluent in Environmentally Sensitive Near-Shore Waters Associated with the South Florida Keys. Journal of Geography and Geology, 6, 164. https://doi.org/10.5539/jgg.v6n4p164

Bacchus, S. T., Bernardes, S., Xu, W., \& Madden, M. (2015). Fractures as Preferential Flowpaths for Aquifer Storage and Recovery (ASR) Injections and Withdrawals: Implications for Environmentally Sensitive Near-Shore Waters, Wetlands of the Greater Everglades Basin and the Regional Karst Aquifer System. Journal of Geography and Geology, 7, 117-155. https://doi.org/10.5539/jgg.v7n2p117

Bacchus, S. T., Hamazaki, T., Britton, K. O., \& Haines, B. L. (2000). Soluble Sugar Composition of Pond-Cypress: A Potential Hydroecological Indicator of Groundwater Perturbations. Journal of the American Water Resources Association, 36, 55-65. https://doi.org/10.1111/j.1752-1688.2000.tb04248.x

Bacchus, S. T., Masour, J., Madden, M., Jordan, T., \& Meng, Q. (2011). Geospatial Analysis of Depressional Wetlands near Peace River Watershed Phosphate Mines, Florida, USA. Environmental and Engineering Geoscience, 17, 391-415. https://doi.org/10.2113/gseegeosci.17.4.391

Bernardes, S., He, J., Bacchus, S. T., Madden, M., \& Jordan, T. (2014). Mitigation Banks and Other Conservation Lands at Risk from Preferential Groundwater Flow and Hydroperiod Alterations by Existing and Proposed Northeast Florida Mines. Journal of Sustainable Development, 7, 225. https://doi.org/10.5539/jsd.v7n4p225

Cangialosi, J. P., Latto, A. S., \& Berg, R. (2018). National Hurricane Center Tropical Cyclone Report Hurricane Irma (AL112017) 20 August.

http://www.nhc.noaa.gov/data/tcr/AL112017_Irma.pdf

Dewberry (2017). Suwannee River LiDAR Project. Project Report Produced for the Unit- 
ed States Geological Survey. Received from the Suwannee River Water Management District on June 5, 2018.

Digital Aerial Solutions (2013). LiDAR Collection, Processing, and QA/QC. Project Report Produced for the United States Geological Survey. Received from the Suwannee River Water Management District on June 5, 2018.

Faulkner, G. L. (1973). Geohydrology of the Cross-Florida Barge Canal Area with Special Reference to the Ocala Vicinity. In U. S. Geological Survey Water Resources Investigation Report 1-73 (p. 125).

Florida Department of Transportation FDOT (1973). Map of Lineaments in the State of Florida. Tallahassee, FL: Florida Department of Transportation.

Florida Natural Areas Inventory, \& Florida Department of Natural Resources (1990). Guide to the Natural Communities of Florida (p. 120). Tallahassee, FL: Florida Department of Natural Resources.

Jackson, G. (1997). Mining a Controversy Babbitt Asks That DuPont Halt Plans. The Florida Times Union.

Krause, R. E., \& Randolph, R. B. (1989). Hydrology of the Floridan Aquifer System in Southeast Georgia and Adjacent Parts of Florida and South Carolina. US Geological Survey.

Lewelling, B. R., Tihansky, A. B., \& Kindinger, J. L. (1998). Assessment of the Hydraulic Connection between Ground Water and the Peace River, West-Central Florida (p. 96). U. S. Geological Survey Water-Resources Investigations Report, 97-4211.

Lines, J. P., Bernardes, S., He, J., Zhang, S., Bacchus, S. T., Madden, M., \& Jordan, T. (2012). Preferential Groundwater Flow Pathways and Hydroperiod Alterations Indicated by Georectified Lineaments and Sinkholes at Proposed Karst Nuclear Powerplant and Mine Sites. Journal of Sustainable Development, 5, 78. https://doi.org/10.5539/jsd.v5n12p78

Marrett, R., Ortega, O. J., \& Kelsey, C. M. (1999). Extent of Power-Law Scaling for Natural Fractures in Rock. Geology, 27, 799-802.

https://doi.org/10.1130/0091-7613(1999)027<0799:EOPLSF>2.3.CO;2

Metz, P. A., \& Lewelling, B. R. (2009). Hydrologic Conditions that Influence Streamflow Losses in a Karst Region of the Upper Peace River, Polk County, Florida (p. 82). U.S. Geological Survey Scientific Investigations Report, 2009-5140.

Miller, D., Bacchus, S. T., \& Miller, H. (1993). Chemical Differences between Stressed and Unstressed Individuals of Baldcypress (Taxodium distichum). Florida Scientist, 56, 178-184.

Miller, J. A. (1986). Hydrogeologic Framework of the Floridan Aquifer System in Florida and in Parts of Georgia, Alabama, and South Carolina. US Geological Survey.

National Hurricane Center (1964). Hurricane Dora September 7-15, 1964. National Oceanic and Atmospheric Administration Reports.

https://www.wunderground.com/hurricane/noaareports/at196406.pdf

National Oceanic and Atmospheric Administration NOAA (1964). Hurricane Dora, August 28-September 16, 1964, Preliminary Report with Advisories and Bulletins Issued. Weather Bureau Hurricane Series. https://www.wunderground.com/hurricane/noaareports/at196406.pdf

National Oceanic and Atmospheric Administration NOAA (2016). Hurricane Hermine. https://www.nhc.noaa.gov/data/tcr/AL092016_Hermine.pdf

National Oceanic and Atmospheric Administration Office for Coastal Management NOAA (2017). Detailed Method for Mapping Sea Level Rise Inundation. 
https://coast.noaa.gov/data/digitalcoast/pdf/slr-inundation-methods.pdf

National Oceanic and Atmospheric Administration Office for Coastal Management NOAA (2019). Atlantic-Caribbean Sea-Gulf of Mexico. https://www.nhc.noaa.gov

Northrop Grumman (2011). Technical Standards Report Control Survey \& Specific Purpose Survey for LiDAR. Project Report Produced for the United States Geological Survey. The Suwannee River Water Management District on June 5, 2018.

Ortega, O. J., \& Marrett, R. A. (2000). Prediction of Macrofracture Properties Using Microfracture Information, Mesaverde Group Sandstones, San Juan Basin, New Mexico. Journal of Structural Geology, 22, 571-588. https://doi.org/10.1016/S0191-8141(99)00186-8

Parameter-Elevation Regressions on Independent Slopes Model Climate Group PRISM (2018a). PRISM Climate Data. https://earthengine.google.com

Parameter-Elevation Regressions on Independent Slopes Model Climate Group PRISM (2018b). PRISM Time Series Values for Individual Locations. http://www.prism.oregonstate.edu/explorer

Rosenau, J. C., Faulkner, G. L., Hendry, C. W., \& Hull, R. W. (1977). Springs of Florida (494 p.). Tallahassee, FL: Florida Bureau of Geology Bulletin 31.

Stewart, M. T., \& Stedje, D. (1990). Geophysical Investigation of Cypress Domes, West Central Florida. Brooksville, FL: University of South Florida Geology Department for Southwest Florida Water Management District.

United States Department of Agriculture USDA (2018). About the Natural Resources Conservation Service. https://www.nrcs.usda.gov/wps/portal/nrcs/main/national/about

United States Fish and Wildlife Service USFWS (2007). Endangered and Threatened Wildlife and Plants; Designation of Critical Habitat for Five Endangered and Two Threatened Mussels in Four Northeast Gulf of Mexico Drainages. Federal Register.

United States Geological Survey National Water Information System USGS NWIS (2018). Instantaneous Graphs with Statistics for Stream Discharge and Gage Height. https://waterdata.usgs.gov/fl/nwis/rt

Vernon, R. O. (1951). Geology of Citrus and Levy Counties, Florida. Florida Geological Survey.

Watson, J., Stedje, D., Barcelo, M., \& Stewart, M. (1990). Hydrogeologic Investigation of Cypress Dome Wetlands in Well Field Areas North of Tampa, Florida. In Proceedings of the Focus Eastern Conference (pp. 163-176). Dublin, OH: National Water Well Association.

Xu, W., Bernardes, S., Bacchus, S. T., \& Madden, M. (2016). Mapped Fractures and Sinkholes in the Coastal Plain of Florida and Georgia to Infer Environmental Impacts from Aquifer Storage and Recovery (ASR) and Supply Wells in the Regional Karst Floridan Aquifer System. Journal of Geography and Geology, 8, 76-110.

https://doi.org/10.5539/jgg.v8n2p76 